Historic, Archive Document

Do not assume content reflects current scientific knowledge, policies, or practices. 



\section{The Imperial Everbearing Strawberry}

An entire $1 \mathrm{y}$ new variety now being offered for the first time. We own and control the only stock of IMPERIAL plants in existence, and are now offering our customers a strawberry that we firmly believe is the best and heaviest yielding: everbearer of all time.

IMPERIAL was first originated several years ago, being secured through a cross with Champion, which it somewhat resembles. Since then, through careful selection of the best and heaviest yielding plants, it has been bred to its present high state of perfection, so that we now consider it well worthy of introduction, and are confident that IMPERIAL will create for itself an enviable and lasting reputation in the strawberry world.

In producing IMPERIAL we have largely overcome one of the big drawbacks that heretofore has been prominent in practically all ever-bearers. No matter how prolific they might be, there has been a tendency for the berries to be very small in size after the first three or four pickings. This has been practically eliminated in IMPERIAL, for it holds its size well, even to the last picking, making it possible, from tests conducted during the past two summers, to produce more crates of large sized, marketable berries from an acre of IMPERIAL than from other varieties; and greater yields mean larger profits.

In size of berry, flavor, color, firmness and keeping qualities, IMPERIAL is ahead of Champion. In fact we know of only one everbearer that is superior in size-that is Mastodon; which nearly everyone agrees is the largest of all everbearers.

IMPERIAL is a long, deep rooted plant, which is the secret of its great success; for it is able to get plenty of moisture from the deeper soil levels during the dry summer and autumn months, so that it keeps right on growing big, thrifty berries, when other kinds run small and dry up.

Our advice concerning everbearers is to plant IMPERIAL for the summer and early autumn crop, followed by Mastodon for late autumn. The two make a combination you simply can't beat.

In order that we may control the production and sale of this wonderful everbearer in future years, we are requiring every purchaser of IMPERIAL to sign the agreement on page 19, whereby he promises not to sell, give away, or otherwise dispose of any of these plants for five years. Be sure to sign this agreement, which is on the back of our order sheet; otherwise we cannot fill your order.

Prices: 12 plants, $\$ 2.00 ; 25$ plants, $\$ 3.50 ; 50$ plants, $\$ 6.00 ; 75$ plants, $\$ 8.25 ; 100$ plants, $\$ 10.00$; 300 to 500 plants at $\$ 8.00$ per 100 . No more than 500 plants to any one purchaser.

\section{Liberal Trial Planting of Imperial Free to Early Cash Buyers}

We think so much of this wonderful berry that we are willing to give a liberal trial planting of Imperial free to early cash huyers, in order to secure as great a distribution as possible the first year, and stimulate planting next year, for we know that after ynu have seen this wonderful everbearer you will spread the good news and buy more. See page 23 for full details of this most wonderful offer. 


\section{Who We Were---Who We Are And What We Hope To Be.}

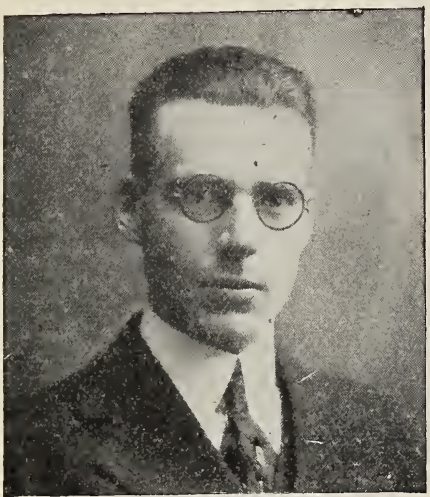

R. C. WHITTEN

To know something of any organization with whom we contemplate business dealings, of the men behind the organization, and a brief history of the enterprise itself; all usually prove interesting to most of us. And so it is that in presenting the catalog of The Whitten-Ackerman Nurseries, we would tell you something of who we were, and who we are.

To begin with, we are not novices in our line, as the

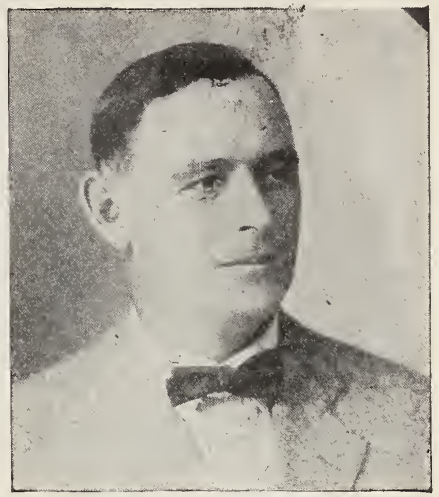

R. W. ACKERMAN

Nursery business has been our life work, and the life work of our fathers before us.

Many years ago-in 1890 to be exact-C. E. Whitten founded here in Bridgman one of the first nurseries established in this part of Michigan. Founded on the principles of strict honesty and absolutely square dealings with its customers, this business grew in time to one of the best known of its kind. In later years the founder was joined by his son, R. C. Whitten, and the business was continued under the name of C. E. Whitten \& Son, up to and including the Spring season of 1923.

The year 1891 saw the foundation of A. R. Weston \& Co., another of Michigan's pioneer nurseries. Within a few years of its establishment, the management was taken over by $\mathrm{F}$. L. Ackerman, who was joined in time by his son, R. W. Ackerman. These men also believed that honesty is the best policy, carrying out their belief in every transaction of their business, so that by the year 1923, A. R. Weston \& Co., under the able Ackerman management, had become one of the largest small fruit nurseries in the country.

In the spring of $1923 \mathrm{R}$. C. Whitten, then owner of C. E. Whitten \& Son, and R. W. Ackerman, Manager of A. R. Weston \& Co., consolidated with the O. A. D. Baldwin Nursery, and organized The Baldwin-Whitten-Ackerman Nurseries, Inc.

For three years this organization continued, until June 14th, 1926, when R. C. Whitten and R. W. Ackerman severed their connection with The Baldwin-Whitten-Ackerman Nurseries, Inc., and organized The Whitten-Ackerman Nurseries. These two men, who have continuously been engaged in the nursery business for the past twenty years, are now ready to serve their customers with the same honest, careful and helpful consideration to the wishes of their patrons as has been heretofore accomplished by the families of Whitten and Ackerman for two generations.

To you who meet us through these pages, we promise the most careful attention to your orders when placed with us; the very best of nursery stock at the lowest prices possible for a really dependable, worthwhile product; and more than this, we promise you an absolutely fair and honest deal from start to finish, for we guarantee satisfaction to the customer. We do not even ask you to depend upon our honesty for the fulfillment of these promises, for we have arranged a most unique selling plan whereby we place the order in your hands for examination and approval before you entrust us with a penny of your money. What could be more fair? On the next page we give the full details of this wonderful plan.

If your order is entrusted to us it will receive our personal attention, and will be taken care of in the same efficient manner as we have served our customers in the past, making you a friend and customer always, so that in time you will come to depend on the name "WhittenAckerman" as a sure source of honest and reliable nursery products. You are to be the judge, and on your decision depends the fulfillment of what we hope to be in the future. 


\section{No Cash Payment before Shipment! Examine Stock before You Pay!}

THIS OFFER APPLIES ON ORDERS AMOUNTING TO \$3.00 OR MORE, FOR SHIPMENT ON OR BEFORE APRIL 20TH, 1927.

Under the terms of our selling plan, it is possible for customers to order without sending any money. Make out your order at prices found on Page 22, and instruct us to ship by C. O. D. Express or Parcel Post, subject to your examination by Express only, as the Postal authorities do not permit examination of parcel post shipments.

Look over the shipment and see for yourself whether the stock is in good condition. If shipment is satisfactory, pay your express agent the amount due, and the plants are yours-still covered by our guarantee. What could be more fair? We simply must furnish good nursery stock, or we couldn't possibly afford to make this offer.

We would advise all small shipments sent by mail, and will send your order by C. O. D. Parcel Post if you prefer. All such shipments are fully covered by our guarantee.

NOTICE: The above offer does not apply on orders amounting to less than $\$ 3.00$, or on any orders specifying shipment later than April 20th, 1927. Cash in full must accompany orders under $\$ 3.00$, or those calling for shipment after April 20th; but on such orders you will be entitled to our cash discount of 10 per cent from regular catalog rates. WE GUARANTEE SAFE ARRIVAL OF ALL SHIPMENTS MADE ON OR BEFORE MAY 25TH, 1927.

\section{0\% Discount For All Cash Orders}

No Time Iimit-Applies On All Cash Orders For Shipment Any Time During 1927.

To those who wish to send all cash with order, we offer a cash discount of 10 per cent from our regular printed prices on page 22, applying on all orders for shipment any time during 1927, when order is accompanied by cash in full.

This is your opportunity to effect a material cash saving, especially on larger orders. Remember, we guarantee safe arrival of all shipments made on or before May 25th, 1927. You take no chances whatever.

\section{Why We Can Sell at Wholesale Prices}

We expect you are wondering how it can be possible for any concern to sell strictly high grade plants and shrubs at such low rates. Well, here's just why we can do it.

1st. You have already noticed the entire absence of color from this little catalog. This same book printed in natural colors would have cost several thousand dollars more. Who pays for the colored catalog? The customer. We've saved that expense to divide among you.

2nd. Another big saving. Buying no large advertising space. Some large nursery advertisements that are now appearing cost three and four thousand dollars for just one insertion. Who pays for these big advertisements? The customer.

3rd. By selling direct through our catalog to planters. We have no agent's commission, which would amount to at least one fourth of your order.

\section{THE BRIDGMAN STATE BANK}

\section{BRIDGMAN.MICH}

sanuarg 4th 1927

TO WHOY TH TS MAY CONCERN

The thiclen-ackerman Nursery Company of Bridgmad. Michlgan, is composed of R. Ackerman and R. C. Whicten, both of whom in the growing and selling of nursery stock. Without favor, we can
recomend them as being nonest and reliable and any business intrusted to them, will at all times receive theit prompt and courteous attention.

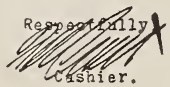

No/

What Our Banker Thinks of $\mathrm{U}_{\mathrm{g}}$.
However, our many economies don't end with what we can save on catalogs and advertising. That's just the beginning. We are always "on the job", cutting the corners here, and avoiding waste there, so that by the end of the year we are able to effect a big saving in both production and sales costs.

There are a lot of dependable nurseries throughout the country who can furnish you with mighty good plants and trees, but why pay a big price when stock equally as good or better can be bought for less? We'll be here in business when the trees and plants you buy of us are bearing fruit. Also, we ship C. O. D. for your approval. They must be right.

Although we sell at Wholesale Prices, we are not in any way connected with any of the so-called "Wholesale Nurseries" heretofore operating out of Bridgman or other nearby Michigan points. The only nursery concern in which we are interested is The Whitten-Ackerman Nurseries, and we sell only a high grade guaranteed product.

\section{REFERENCES}

We refer you to The Bridgman State Bank, or either the Express Agent or Postmaster at Bridgman, where we have lived all our lives. 


\section{STRAWBERRIES}

PREMIER-The exceptionally satisfactory and unusually profitable crops secured from Premier have made it first choice among all successful strawberry growers throughout the country who know and demand the best, and who have found from their own experience that Premier will produce more dollars per acre, with a bigger crop certainty, than any other variety offered today.

Premier is the earliest worth while strawberry we know of. This feature alone makes it a great money maker, for it yields its fruit crop at a time when strawberries are in great demand, and buyers everywhere are willing and anxious to snap up every available quart of Premier, paying the highest prices for this fancy, early fruit.

Premier is unusually healthy, being free from leaf spot and other diseases. Its deep, heavy roots enable it to easily withstand dry weather, and mature a full crop of big berries when many varieties are a complete failure.

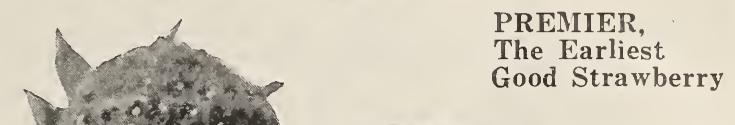

PREMIER,

Good Strawberry

Remember, our stock is from the original, heary fruiting strain, bearing our true-to-name guarantee.

COOPER-Beyond question this variety yields the biggest strawberries ever produced. Its large, bushy plants are full of vigor and vitality that enable it to be grown successfully in all soils and climates. The flavor of its fruit is delicious; often being compared to that of the wild

\section{SPEGIAL PRICES TO COMMERCIAL PLANTERS \\ A glance at our Price List on Page 22 will convince sou that our but we can better these considerably on quantity lots. \\ on quantity lots. of several thousand plants, it will pay you to write for special prices, which will be quoted promptly.}

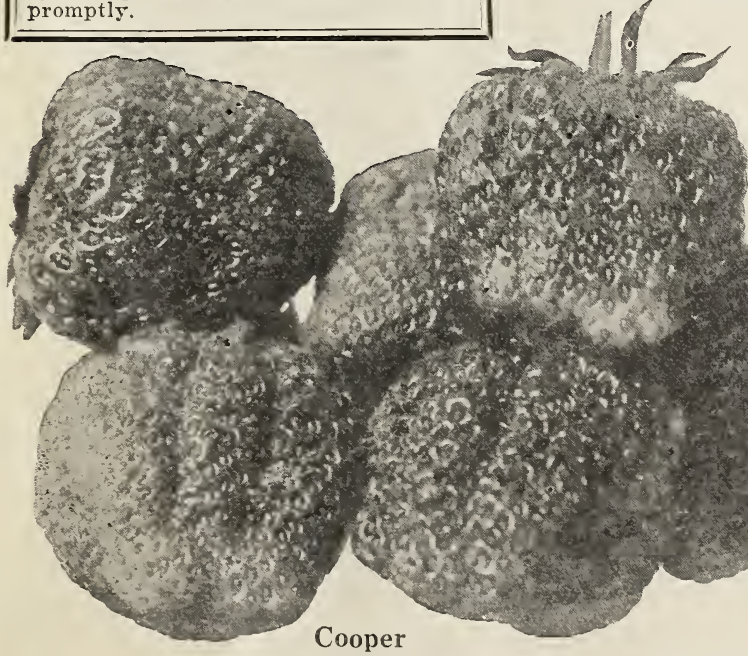
at big prices.
Cooper produces its crop early in the season, and is especially adapted to fancy, local market trade, where its large size and attractive appearance result in quick sales

\section{FIVE GOOD REASONS FOR PLACING YOUR ORDER WITH US}

1. A Discount of $10 \%$ from Catalog Prices On All Cash Orders Any Time During the Year.

2. An Opportunity to Examine Plants Before You Pay. See Just What You Are Buying and Make Satisfaction a Certainty.

3. Bigger Values for Less Money.

4. If Not Received In Satisfactory Condition, Stock Is Replaced Free of Charge or Money Refunded. We Don't Ask Half-Price for Replacements.

5. Every Order Receives Our Own Personal Attention.

Certificate of Nursery Stock Inspection No. 32

This is to Certify that the nursery stock of Whitten-Ackerman Nursery, Bridgman, Michigan, has been examined and found apparently free ously contagious tree and plant dis. eases.

L. WHITNEY WATKINS, Com. This Certificate yoid after July 31, 1927 Bureau of Agricultural Industry, A. C. Carton, Dir E. C. Mandenberg, Orchard and Nursery Inspection. Lansing, Mich, October 20th, 1926. 


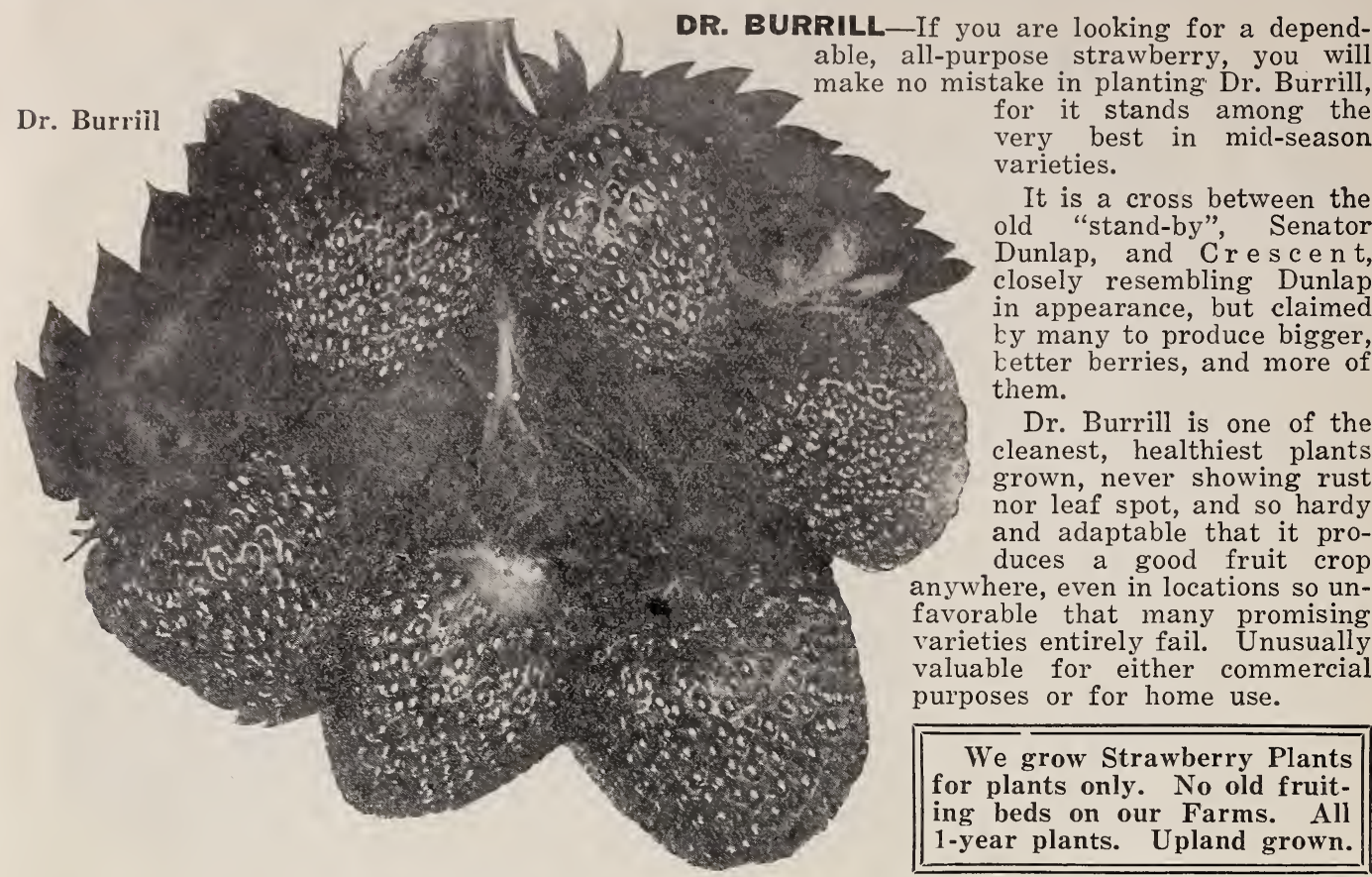

\section{Senator Dunlap-Always Satisfies}

Strawberries come, and strawberries go; each year bringing forth the newer introductions that find their way into the market, often backed by brilliantly colored illustrations depicting tremenduous size, claims of almost unbelievable qualities, and promises of superiority, which, for a time at least, have some of the old time favorites backed clear off the map.

This, however, has not been the case with Sen. Dunlap. It is one of the oldest varieties commonly planted today, and never for a single season since its first appearance vears ago, has it lost even the smallest part of its well earned popularity that has made it famous the world over.

At the present time there are probably more Sen. Dunlap being planted than ever before, proving conclusively that it is one of the surest and most dependable all-purpose strawberries ever offered.

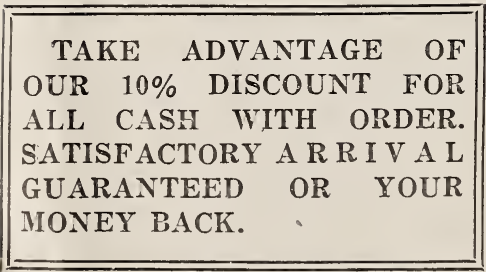

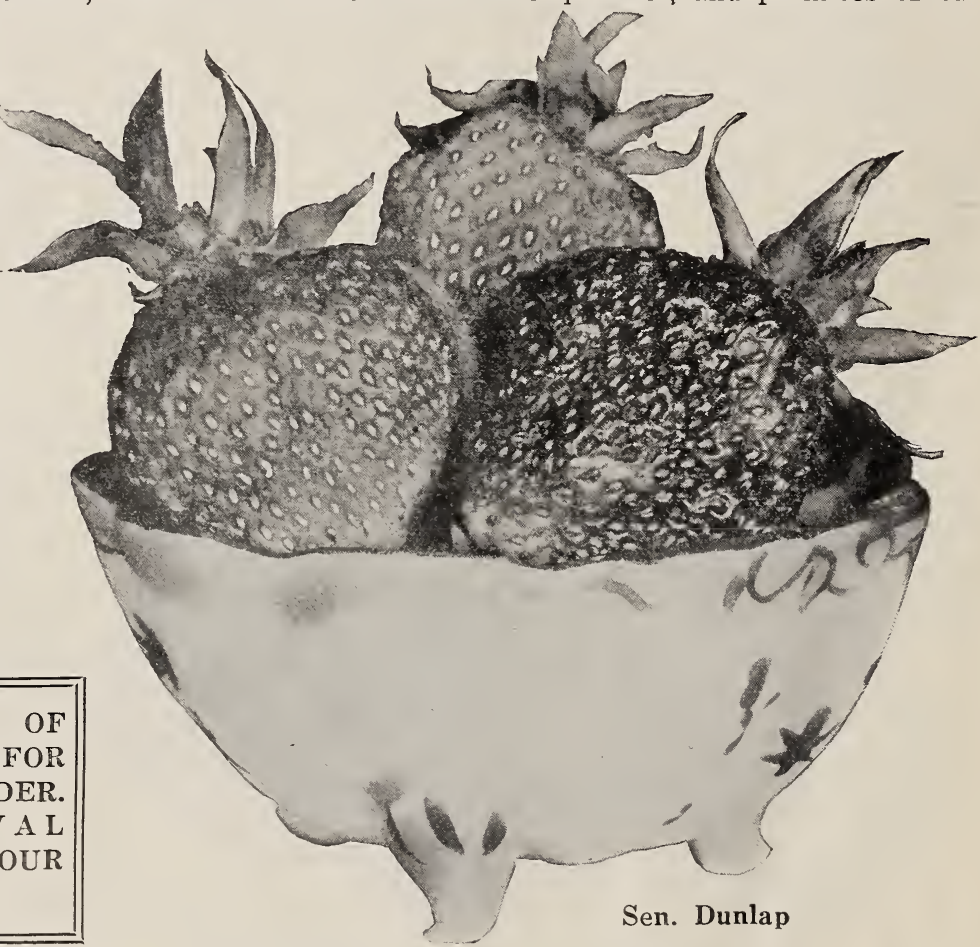


PEARL-By many this has been referred to as "The Latest Strawberry Without a Fault." Unquestionably it is the latest, often ripening its fruit as late as the Fourth of July; and if it has any faults, we have failed to find them after growing Pearl for several years.

The fruit is everything that could be asked for to make it an ideal market cerry. It is large in size, dark red to the heart, firm quality, with a tough outer skin that gives it unusual firmness and keeping qualities. Its prominent vellow seeds add the finishing touch to its attractiveness, and as it possesses a most delicate flavor, and is a heary and sure cropper, what more could be asked for to make it an ideal late berry? When Pearl is in its prime, other varieties are off the market, and as it has the field to itself, the prices paid for Pearl are quite naturally the highest.

As a word of caution to those intending to plant Pearl, we would say that for the past two or three years, a rather inferior berry of imperfect bloom has been masquerading under this name in some of the Eastern states, bringing disappointment to those who have grown it.

Our supply is a strongly perfect flowering variety, and as our original propagating stock was purchased direct from the originator in Ohio, we can promise our customers genuine Pearl that will surely please them in every way.

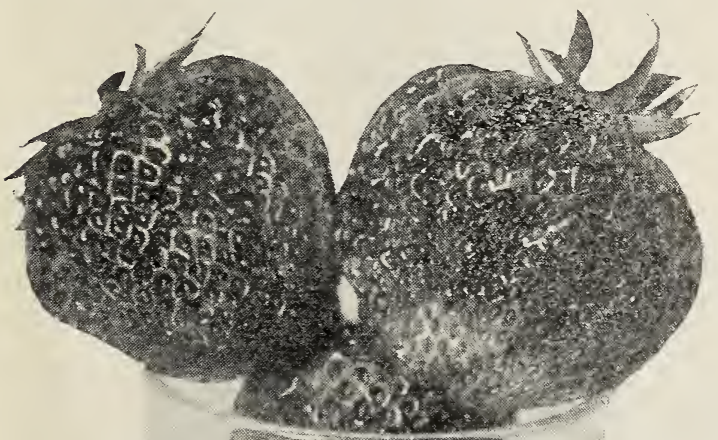

\section{NOTICE TO PLANTERS}

All varieties of strawberries described in this catalog (with the one exception, Sample) are perfect flowering, and can be planted alone, requiring no other kind as a pollenizer. Sample should be mated with some perfect flowering medium or late variety.

AROMA-Here is another good late variety and until the advent of Pearl, Aroma was long considered the standard late market strawberry. It is still grown extensively in all sections of the country, but is especially popular in the Southern states, where many fruit growers' associations plant Aroma exclusively.

The berries are large, nearly round, and of firm texture, deep red in color and good flavor, making it ideal for shipping. Although good yields are sometimes produced on light ground, Aroma is at its best on the heavier soils.

SAMPLE-Ripens medium late to late, and covers a very long fruiting season. Berries large, regular in size, and well flavored. An imperfect flowering sort that should be grown with some medium to late perfect variety as a pollenizer. Sample has long been a favorite with many who know it, and is well worth planting in a limited way.

\section{A SATISFIED CUSTOMER}

Oklahoma, Dec. 21, 1925.

The Whitten-Ackerman Nurseries,

Bridgman, Michigan.

Gentlemen:- I enclose check for $\$ 56.00$ in payment of account, and thank you for the good stock sent. Yours truly, J. Parker.

WE'LL SHIP FOR YOUR APPROVAL WITHOUT A PENNY DOWN 


\section{Eaton - the Strawberry Supreme}

Introduced by Mr. Whitten several years ago. Eaton immediately made a place for itself in the strawberiy world, and almost over night became known as "The Standard of Excellence" wherever strawberries are known and grown.

Eaton is a mid-season or main crop variety, of unusually long fruiting season, probably producing heavier yields of large sized berries than any other variety of its class or kind. The flavor of the fruit is all that could be desired. It is unusually firm in texture, which, combined with its wonderfully attractive appearance, gives it all the necessary qualities of a successful market strawberry.

No other variety can excel Eaton in flavor, quality, productiveness, firmness and keeping qualities, so that it is beyond all question one of the greatest and most profitable strawberries ever produced, for either market or home use. Remember, we have the original Whitten strain, guaranteed absolutely true to name.

GIBSON-This has long been knowr as "The Universal Favorite", and probably there never has been a more popular variety, nor one planted any more extensively than Gibson.

It is an unusually safe variety for commercial planting, inEaton asmuch as it always produces a big crop of large marketable berries, seeming to thrive equally well in all sorts of soils and climates. This is a feature hard to find in strawberries, and one that makes a variety especially valuable.

The berries are large, holding their size to the end of the season, and are all that could be asked for in color, flavor, firmness and productiveness.

Gibson is not only an ideal market berry, but one that is especially good for canning, and is one that should be included in every order, large or small.

BUN SPECIAL-One of the newer varieties, introduced in 1920, when for a year or two it gave promise of becoming quite popular.

In size of berry, Bun Special is perhaps above the average, with a rather light red color and glossy surface that give it quite a fancy appearance. For home or nearby markets it can be grown profitably, but our experience has been that it lacks sufficient firmness for shipment to distant markets.

During the past year or two, Bun Special has been discontinued by several nurseries, but we retain it on our list for those of our customers who have tried it and want to grow it again, and for those who want to make a trial planting this year.

We can promise you genuine, true-toname Bun Special, and as an inducement for you to include a few with your order, we have it priced at a figure below its actual value.

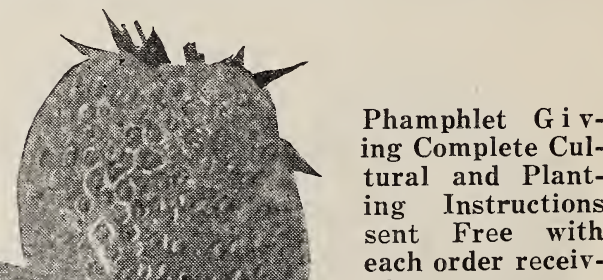
ing Complete Cultural and Plant(1) each order received.

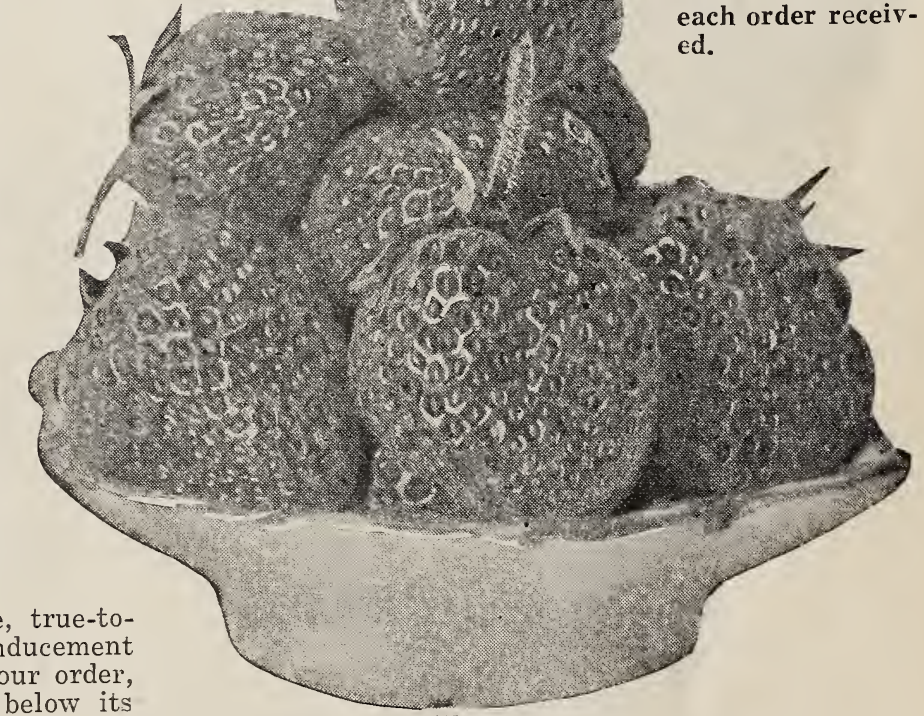

Gibson

WE BELIEVE IN A SQUARE DEAL, AND PRACTICE WHAT WE BELIEVE. 


\section{Everbearing Strawberries}

Since the first Everbearing strawberry made its appearance some twenty-odd years ago, almost countless varieties have been brought out, each one supposed to be an improvement on the other; but of all this great number, some with merit, and many without, the four outstanding varieties are described on this page, and we can honestly recommend all of them as good, dependable kinds that are certain to do all we claim for them, and produce money making crops of berries if planted in quantity, and plenty of fruit for the home table from the average sized garden planting.

Our new IMPERIAL and Champion are both of the old Progressive type, but each one is a distinct improvement over the original Progressive. Where greatest yields in number of crates and a full crop every year, regardless of weather, are the prime consideration, we recommend IMPERIAL and Champion, but if size of berry is the thing

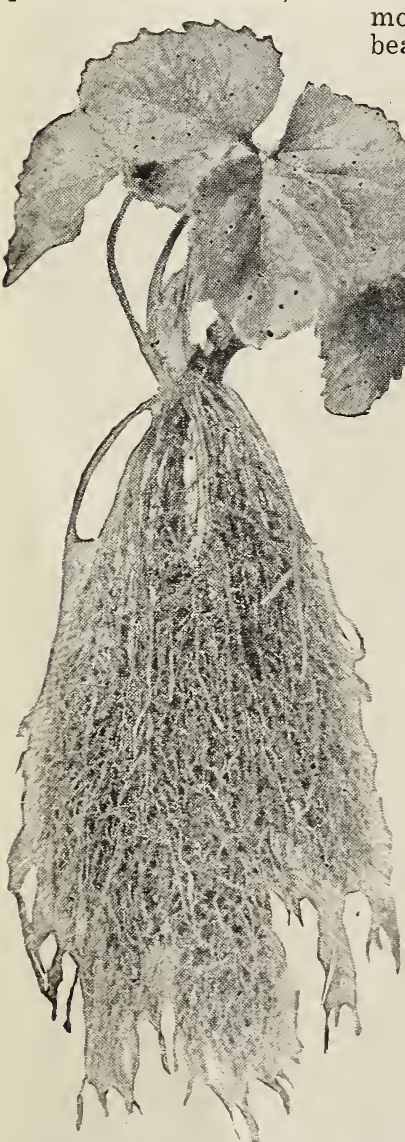
most desired, Mastodon should be your choice, for it is the biggest everbearing strawberry ever heard of.

We have them all, each variety positively guaranteed pure and true to name, all grown from heavy fruiting strains that will produce not only new plants, but berries as well, and plenty of them.

IMPERIAL_The Improved Champion-Illustrated and fully described on inside front cover. Be sure to read about this marvelous everbearer that will produce greater yields and more profits.

CHAMPION-An improved Progessive that is undoubtedly gr: 'n more extensively today than any other everbearer. One that has been tried and tested, and in a few short years came to the front as a proven and worth while variety that is a dependable source of profit and pleasure, year in and year out. Champion has never had a crop failure-something unusual, and something to bear in mind when ordering your everbearers.

PROGRESSIVE-One of the first successful everbearers that has been a favorite for many years. While we consider Champion a marked improvement over this variety, there are some growers who still swear by Progressive, and to cover this demand we have grown a limited supply, which we are offering at a nominal price.

MASTODON-(See front cover for illustration of this wonder berry.) The Introducer's Original Strain.

This new everbearer is of an entirely different type from the older creations that were placed on the market some years earlier. The plant is larger, making a heavier, more rank growth of foliage, dense enough to protect the late autumn blooms from frost, and the summer crop from the hot rays of the sun.

The flavor, color and quality of the fruit are excellent, and the size of the berries surpasses that of any other everbearer produced.

As a general rule, everbearers require a very fertile soil to give really satisfactory results, but in this respect also, Mastodon is different, for a satisfactory fruit crop can be harvested on soil of only average quality.

We have available a goodly supply of Mastodon, and for this reason are offering them to our customers at what we believe is the lowest price available for true-to-name stock, every plant of which

A sample of our heavy rooted bears our guarantee of genuineness and satisfaction. Let us re. Mastodon Plants serve yours now. 


\section{BLACKBERRIES}

ALFRED-The Blackberry Without a Core-This variety has been on the market only two or three years, but in this short length of time has become so popular in many parts of the country that it is fast replacing the old standard kinds.

Alfred bears young, producing nearly a full crop of fruit the year after planting. It is a vigorous grower, producing strong, well branched canes, perfectly capable of carrying the big crop of fruit produced. It is perfectly hardy, and can be grown anywhere without winter protection, having withstood a temperature of 30 degrees below zero with absolutely no injury resulting.

Alfred ripens early, beginning a week in advance of other varieties, and continues over a long season. The berries are of immense size, some berries measuring three inches around and two inches in length. The color is a glossy, jet black, and the flavor sweet and delicious. Combining all of these qualities with its exceptional productiveness makes Alfred a leader among blackberries.

We have a fine stock of root cutting plants to offer, secured direct from the introducer, so we can promise you genuine MERSEREAU_Originated in Northern New York, Alfred, and at a price you and on account of its hardiness and freedom cannot duplicate
elsewhere.

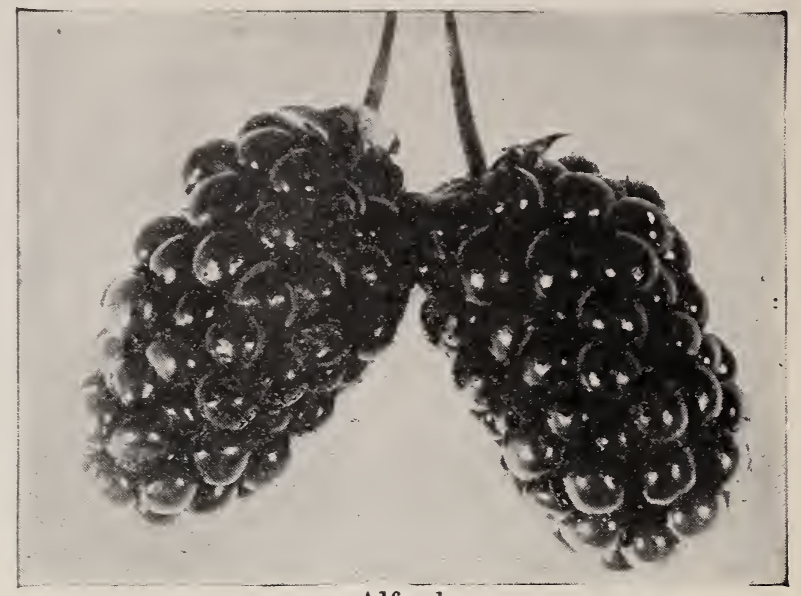

Alfred in the colder climates, where in many sections it is fast replacing Eldorado, especially on the lighter, sandier soils, as Mersereau is a strong, deep rooted grower, enabling it to bring to maturity a full crop of fruit in seasons so lacking in rain fall that Eldorado and other kinds will produce only two or three pickings.

Mersereau is a mid-season variety, especially suitable as a main crop, and we highly recommend it to our customers as one of the most. satisfactory and profitable blackberries. We have a fine supply of large, healthy root cutting plants, every one of which are sure to grow and thrive.

ELDORADO-This is one of the leading commercial varieties that has long been popular on account of its hardiness, productiveness and freedom from disease, it being especially immune to orange rust, the common enemy of all blackberries.

Berries are of good size, color, flavor and quality, holding up well for shipping, and as it fruits over a long' season, produces heavy yields that insure a good profit to the grower.

We can furnish both suckers and root cutting plants of this variety, but recommend the root cutting plants as preferable, as they are much more certain to live, and will make a quicker growth; which means more berries a year from planting.

LUCRETIA DEWBERRY-Of the blackberry type, but produced on a trailing vine instead of an upright bush. Very hardy and practically immune to disease. Best results are secured on the higher, sandier soils, their natural home. Berries are extra large, lustrous black, sweet and juicy. Always bring a big price in market.

Mersereau, the best main crop Blackberry today. 


\section{Black}

\section{Raspberries}

GREGG-This is one of the most valuable varieties of the entire black cap family. In fact it is the best late market sort we know of.

Gregg is a tremendous producer, yielding great crops of large, firm berries of such excellent quality that it is considered one of the best shippers wherever grown.

Ripening as it does, after Cumberland has produced the main part of its crop, Gregg enters the market at a time when it is not over supplied, and naturally it brings top prices wherever offered.

Gregg is a strong, upright grower, especially free from disease, and producing a large amount of fruiting wood. The berries are large and even in size, excellent quality and firm texture. You will make no mistake in planting Gregg.

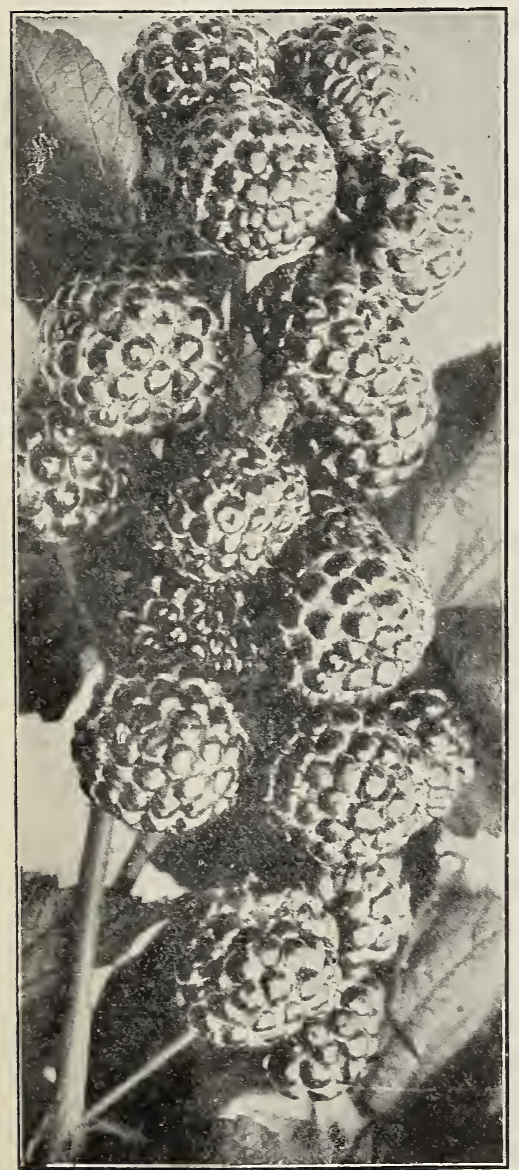

Cumberland

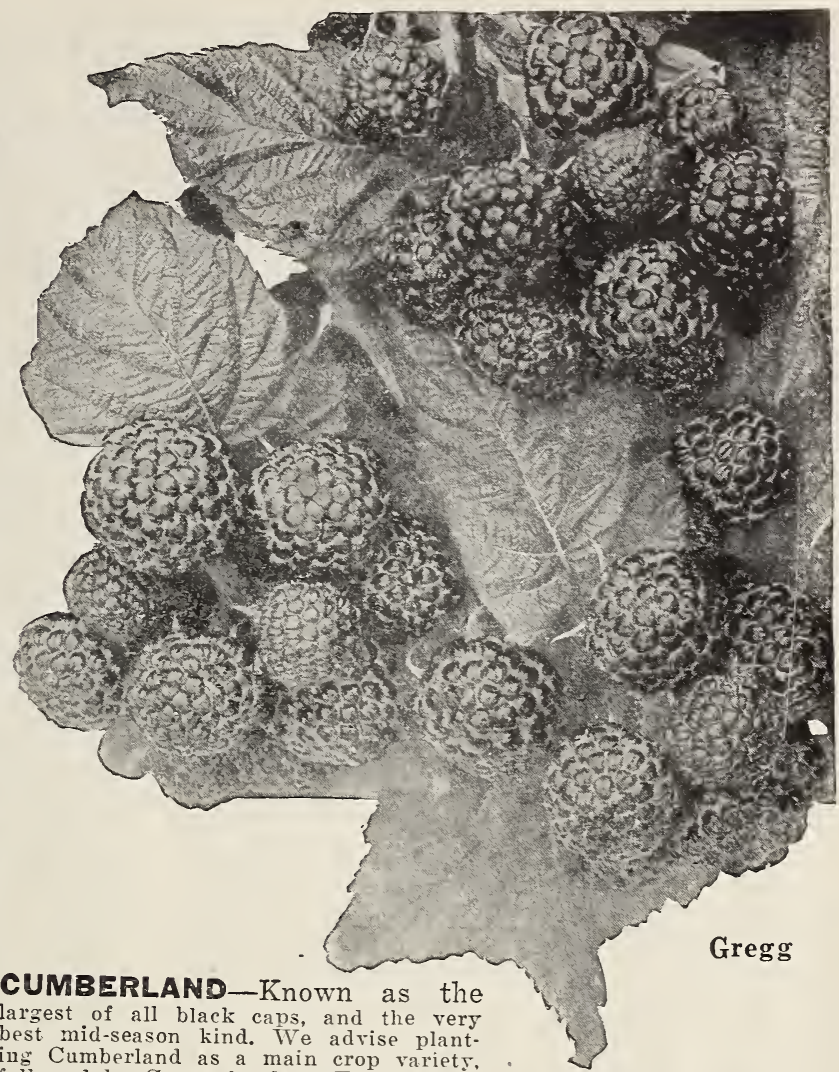

argest of all black best mid-season kind. We advise plant. followed by Gregg for late. Together the

wo make an excellent combination that it is impossible to beat.

No black cap has ever been grown as extensively as Cumberland, nor attained its great popularity in all raspberry producing sections of the country. It is a heavy sielder, the berries large, a rich black in color, fruit firm and of delicious flavor.

The bush is absolutely hardy, vigorous growing, producing plenty of fruiting wood; especially free from anthracrose the all raspberries. Cumberland is the greatest money making black cap of all time.

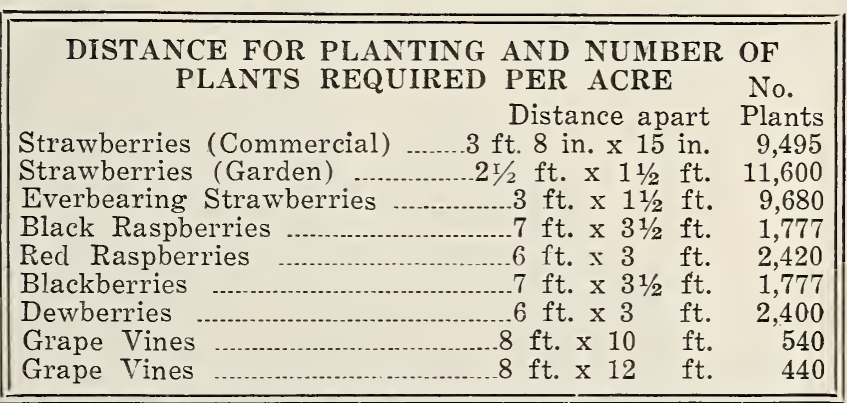

PLUM FARMER-This is the best early black cap in existence. The plants are fine growers, free from disease producing many laterals thus giving lots of fruiting wood, insuring a big crop of fruit: while the berry is very large, and of excellent quality.

Plum Farmer rinens very early, producing most of its fruit in one Treek. Practically the entire crop can be harvested in three large pickings, enabling the grower to reach an early market, and harvest the tabor.

COLUMBIAN PURPLE CAP_Grows like a black cap bush, and propagates in the same manner. No suckers to contend with in row. Is perfectly hardy, and can be grown anywhere without winter protection. Berries are deep purple; flavor fine, rich and delicious. Especially fine for preserves, jam and jell. Columbian plants are always scarce. Better order yours now.

IF YOU PREFER, WE'LL SHIP C. O. D. FOR YOUR APPROVAL 


\section{RED RASPBERRIES}

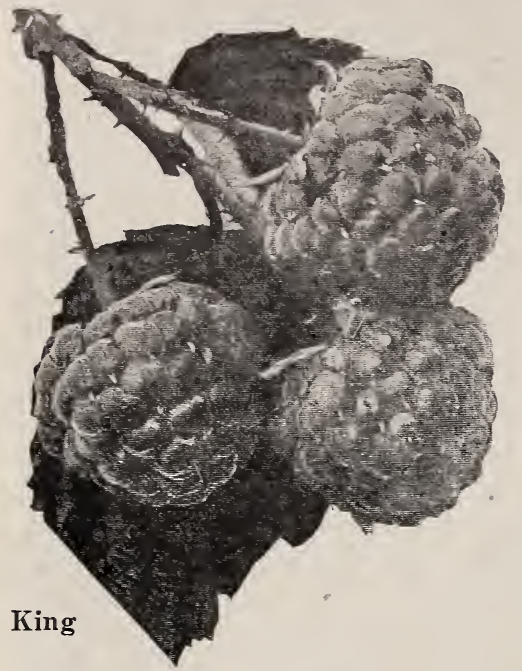

KING-A big crop every year! That's what you're sure to get if you grow King. It is without exception the most profitable early red raspberry ever grown.

Perhaps the most outstanding feature of this variety is its earliness. The first berries usually ripen about the first of July, and heavy fruiting follows for from four to six weeks. The berries are borne in clusters the entire length of the bush, making possible really enormous crops of fruit.

The berries are large, firm and attractive, and are easily picked as they ripen evenly. King thrives equally well on light or heavy soils, and being perfectly hardy, has never been known to winter kill. Be sure to include King in your raspberry order.

\section{LOWER PRICES ON LARQE LOTS}

Notwithstanding our low catalog prices, we are able to quote especially attractive prices on large lots of Red Raspberry plants. Quantity production and a favorable growing season have made this possible. If you need several thousand plants be sure to ask for our special prices before ordering anywhere.

\section{Victory-The Largest of all Red Raspberries}

This variety is of especial value in that it possesses every requirement of a profitable commercial raspberry.

In productiveness, size, quality, flavor and general appearance, Victory is away above the average, and no matter what your soil or local weather conditions, you can plant Victory with safety and every assurance of success, for it originated in Northern Michigan where it has withstood a temperature of 30 degrees below zero without injury to the tip of a single cane.

The quality is of the best, the firmness of its fruit insuring perfect shipping qualities. Victory holds the record of a single bush producing 19 pints of berries in one season. This speaks well for its productiveness. Victory belongs in every raspberry planting, and should be a part of your order without fail.

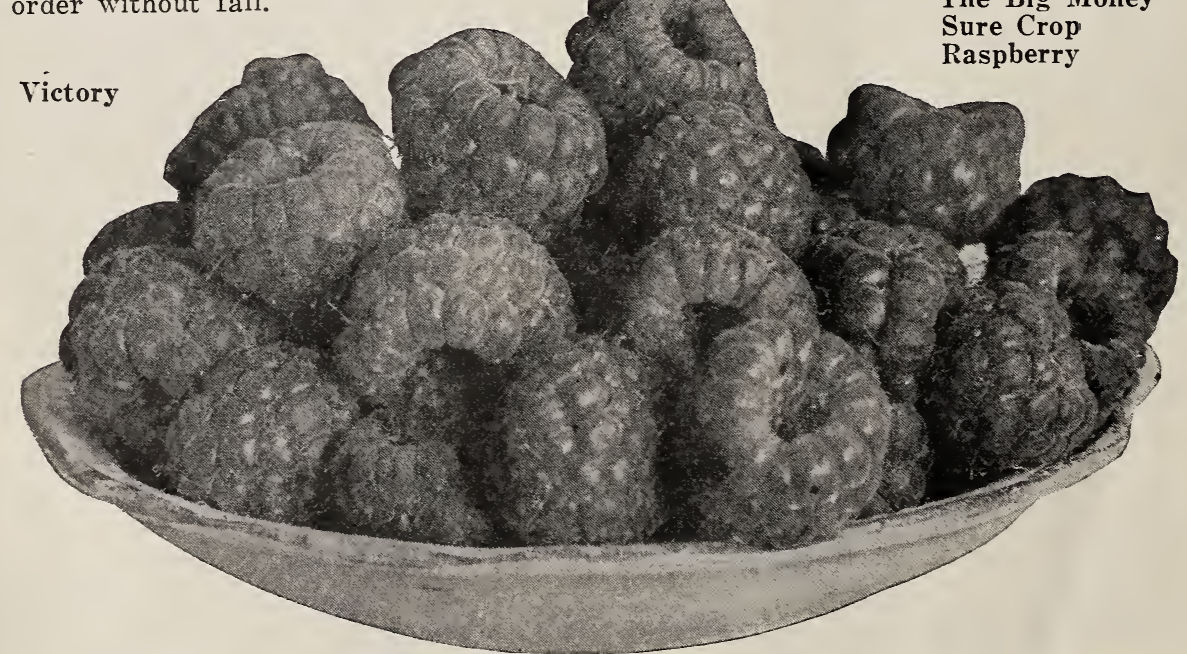

A Liberal Supply Of Our New Imperial Everbearer Sent Free With Your Order See page 23 for details 


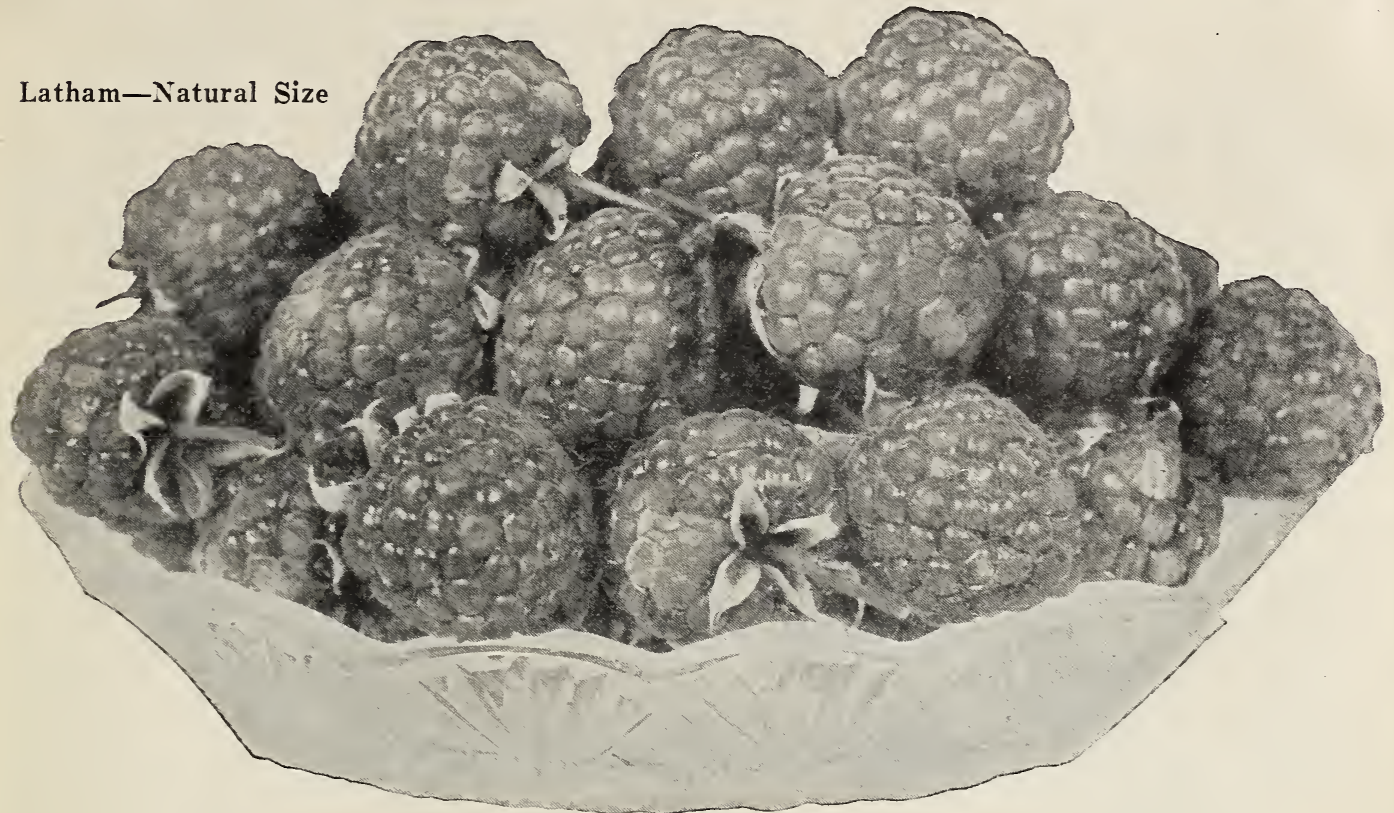

LATHAM-The Queen of the Northwest-This is a com. paratively new variety, originated at the Minnesota State Fruit Breeding Farm, and one that gives promise of becoming very popular in all sections of the country when better known.

This is the same variety that is sometimes sold under the name of "Red Path", but it is generally agreed they are the same.

We have no hesitation in giving Latham our unqualified recommendation, for after fruiting it several years, we have found it to be an ideal berry, of extra good quality, and all that the introducers have claimed for

Latham is a tall, vigorous grower with extra heavy canes, foliage dark green, and extremely free from disease. Fruit ripens same time as Cuthbert, and is an exceedingly productive sort. Much larger than Cuthbert, some berries measuring an inch in diameter. Color is good, quality of the best, with an excellent raspberry flavor. One of the best for either shipping or home use. An ideal canner.

We have a nice stock of both suckers and transplants which we are offering at a very reasonable price. All stock guaranteed disease free and absolutely true to name.

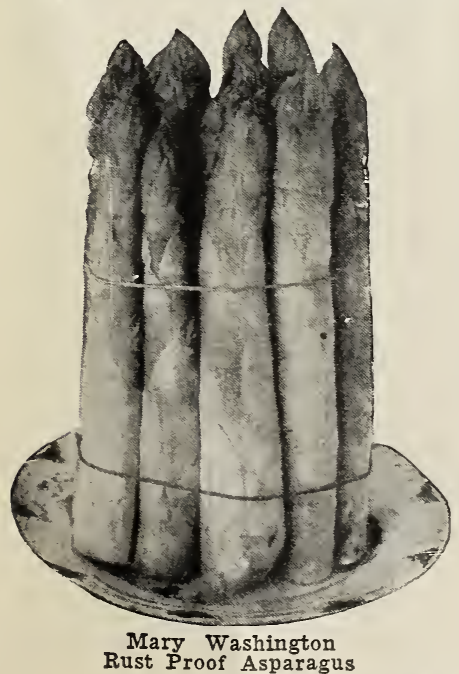

PALMETTO ASPARAGUS-For years the standard market variety. Strong P der to an unusual length. The very test of the common kinds.

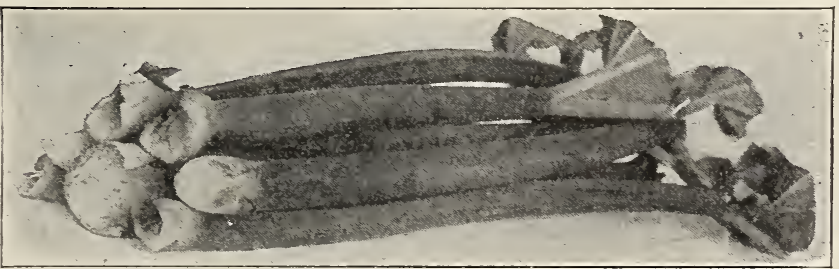

MYATT'S IINNAEUS RHUBARB-Those who have never grown this variety will hardly recognize the old "Pie Plant". It is an early, tender variet5, without being in the least tough or strings, with a mild, sub-acid flavor. We consider this one of the most profitable market garden crops, and one that should be produced more extensively. We offer good, strong roots, priced so low that our customers can purchase in quantities at very little expense.

We Guarantee Satisfaction-See Page 23 


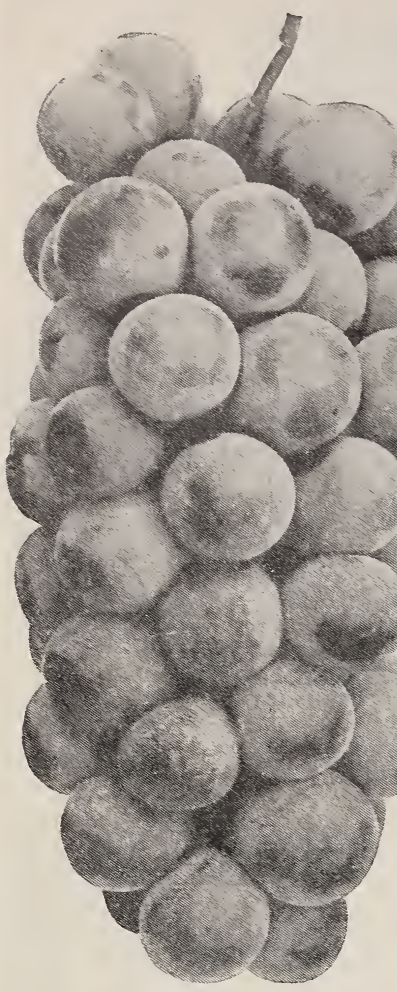

Niagara

\section{GRAPE VINES}

SELECTED VARIETIES-THE BEST OF MANY

Chosen for their Flavor, Size and Productiveness

Every Whitten-Ackerman Grape vine is guaranteed true to name, free from disease, and from productive strains. The cuttings for our grape vines are all taken from bearing vineyards, only the best wood being used, assuring you the best possible quality, and absolute certainty of varieties proving true to name.

Grapes are the easiest of all fruits to grow, thriving anywhere, and on any soil. We offer only No. 1 vines in both one year and two year sizes. We do not handle No. 2 or light grade stock, for a vineyard is a life time investment, and as such is worthy of the best vines. We have them.

CONCORD-A large, purplish-black grape. Decidedly the most popular grape in America, as it adapts itself to varying conditions, and is profitably grown in every grape growing state in the Union. Bunch is large, shouldered and compact. Berries are large, covered with a rich bloom; skin is tender, but amply firm to carry well to distant markets. Flesh is juicy, sweet and tender; excellent flavor. Vine a strong grower; very healthy, hardy and productive. The most reliable and profitable market variety.

NIAGARA-The Most Popular White Grape. This is the leading white variety wherever grapes are grown. Niagara is perfectly hardy, and very productive. Bunches very large and compact; sometimes shouldered. Berries fully as large or larger than Concord, mostly round, yellowish green when fully ripe, slightly amber in sun. The skin is thin but tough and does not crack. Quality of the best, very little pulp, melting and pleasing to the taste. Niagara is a most excellent variety, and of exceptional value for eating, grape juice or market.

CHAMPION-(Black). One of the very earliest varieties to fruit and market. Very productive, splendid shipper and makes a most attractive appearance. Vines are vigorous and hardy. An especially good variety for cold climates. Unusually profitable on account of its extreme earliness, which enables Champion to top the market every year.

MOORE'S EARLY-An early black variety, similar to Concord in looks and quality, but ripening about two weeks earlier. Has a peculiarly sweet flavor of its own. Vines are hardy and good bearers.

AGAWAM-A large, dark red grape. Bunches large, compact, frequently shouldered; berries large, with a thick skin; pulp soft and sweet; vine very vigorous. One of the earliest to ripen.

DELAWARE-Still holds its own as one of the finest grapes. The bunches are small, compact, shouldered; berries rather small, round; skin thin, light red; flesh very juicy, with an exceedingly sweet and delicious flavor; vine vigorous, hardy and productive.

WYOMING-A red variety. Vines very hardy with thick, leathery foliage; berry bright red; large, flesh tender, juicy with strong aroma. Ripens early. One of the best red grapes we know of. Size nearly double that of Delaware.

WHITTEN-ACKERMAN SUPER VALUE GRAPE VINE COLLECTION BARGAIN NO. ONE

6 Concord, 3 Niagara (White), 1 Wyoming (Red). All $1 \mathrm{yr}$. No. 1 vines of our regular grade.

Only $\$ 1.00$, Postpaid Anywhere in U. S.

This Price Net, and subject to no discount. Cash must a company order. 


\section{FRUIT TREES}

We are able to supply commercial orchardists or home planters with any quantity of sturdy, nursery grown trees in Apple, Peach, Pear, Quince, Plum, Apricot and Cherry. We list only the best varieties. Write for special prices on large plantings. Every tree guaranteed fully up to grade, and true to name. Whitten-Ackerman will still be here on the job when those trees come into bearing. That is your protection when ordering here.

\section{APPLES}

BAIDWIN-Winter apple. Large, roundish, dark red, juicy, sub-acid. Good flavor, good cooker, good keeper. Tree vigorous, upright. Planted extensively. DELIĊous- Winter apple. Large; brilliant dark red; blending to golden yellow at blossom end. Flared; blending to golden yellow at blossom end. Flagrained, crisp, juicy, melting and really delicious. Tree hardy, vigorous grower, producing enormous yields.

DUCHESS OF OLDFNBURG-Summer cooking apple. Medium to large; striped, mostly red; good yielder. tree hardy. good bearer; upright grower. Best summer market apple. Planted extensively.

JONATHAN-A grand, good winter apple. Bright, solid red. Flesh white sometimes tinted with red. firm, fine, crisp and tender. Good size, roundish, smooth. Excellent eating apple. McINTosm-One of the very best winter apples. Bright, deep red color, made
more attractive by a heavy,
characteristic bloom, Uniform
Flesh white, tender, juicy, with
a rich, delicious and very dis-

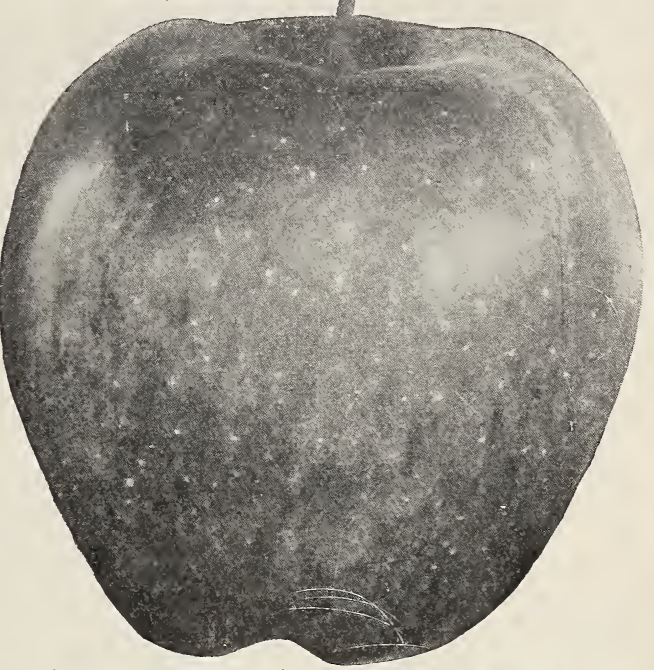

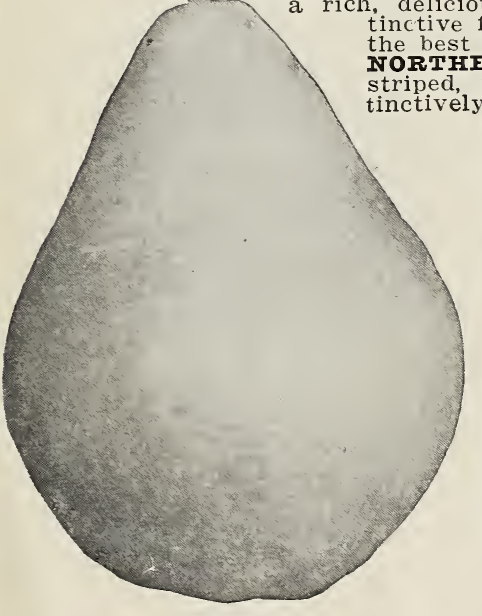

Bartlett

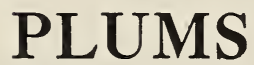

BURBANK-Most profi t a b le BURBANR-Most p ro fita market variety. Ripens in Aug. ust. Tree hardy, spreading, er. Bears young. Fruit large excellent, cherry red.

GERIMAN PRUNE-Large, dark purple, sweet. One of the best for canning. Excellent for drying. Plant a few trees and make your own dried prunes. Ripens in September.

IOMBARD-Medium, violet red, juicy, good, hardy, very productive. One of the best market varieties. Ripens in August.

MONARCH-Very large, roundish oval, perfect freestone. Tree robust; dense foliage, prolific bearer. Ripens in October. One of the best late market rarieties.

\begin{abstract}
delicious flavor.
\end{abstract} bright red color. Flesh tinged with yellow; firm, crisp, with pleasant, rich acid flavor appealing to every one. WEATHY-Ripens late summer and early autumn. Perfectly hardy, vigorous and productive. Fruit large, red streaked with

White. Quality good. TRANSPART-Ripens in July. One of the very best early varieties. Skin is clear white, changing to pale yellow when ripe. Flesh white, tender, sub-acid.

\section{PEARS}

ANJOU-Large, buttery, melting, rich and delicious. One of the best general purpose pears. The best late fall and winter variety. October to January.

BARTIETT-Ripens in August. Best known, high quality pear. One of the choicest canning varieties, and a favorite for all uses. Large, yellow, waxy skin, rich and juicy. Tree hardy; regular and young bearer.

YIIFFER-Best pear for large commercial planting, because of its KIEFFER-Best pear for large commercial planting, because of its in October and November. Fruit large, yellowish, and of good quality.

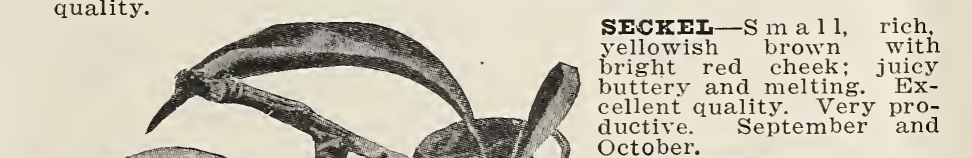

OUR STOCK IS ALL STATE INSPECTED AND DISEASE FREE. 


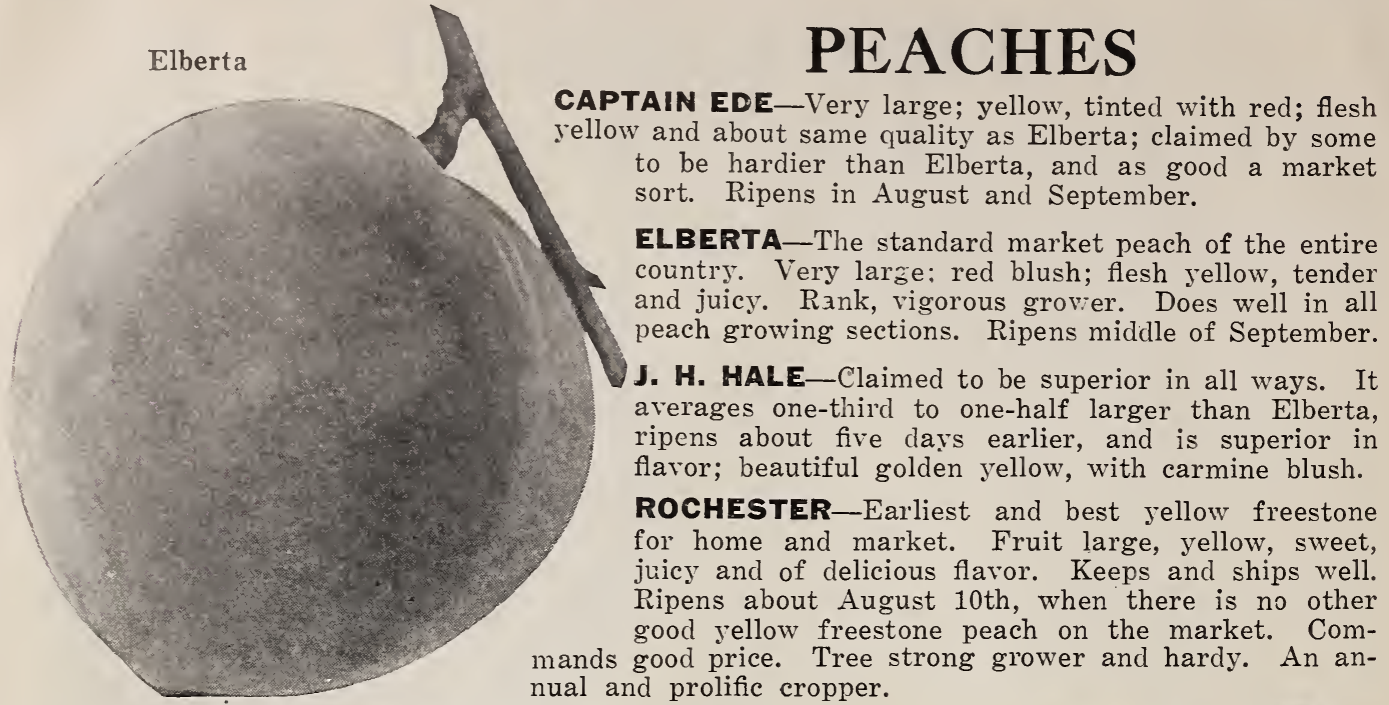

\section{SOUR CHERRIES}

EARLY RICHMOND-Medium size, dark red; acid flavor. One of the most popular sour cherries, and is unsurpassed for cooking purposes. Tree a splendid grower, and exceedingly productive. One of the most hardy. Ripens in June.

LARGE MONTMORENCY-Larger and finer than Early Richmond, and ripens about ten days later. One of the finest flavored sour cherries. Bears enormous crops regularly. Best all-around cherry grown. Tree bears two or three years from planting. Ripens late June and first of July.

\section{SWEET CHERRIES}

BING-One of the best known and most popular dark sweet cherries. Fruit large, dark colored, nearly black. Considered one of the most profitable. Tree hardy and vigorous. Seems to succeed East better than most sweets. Ripens late June.

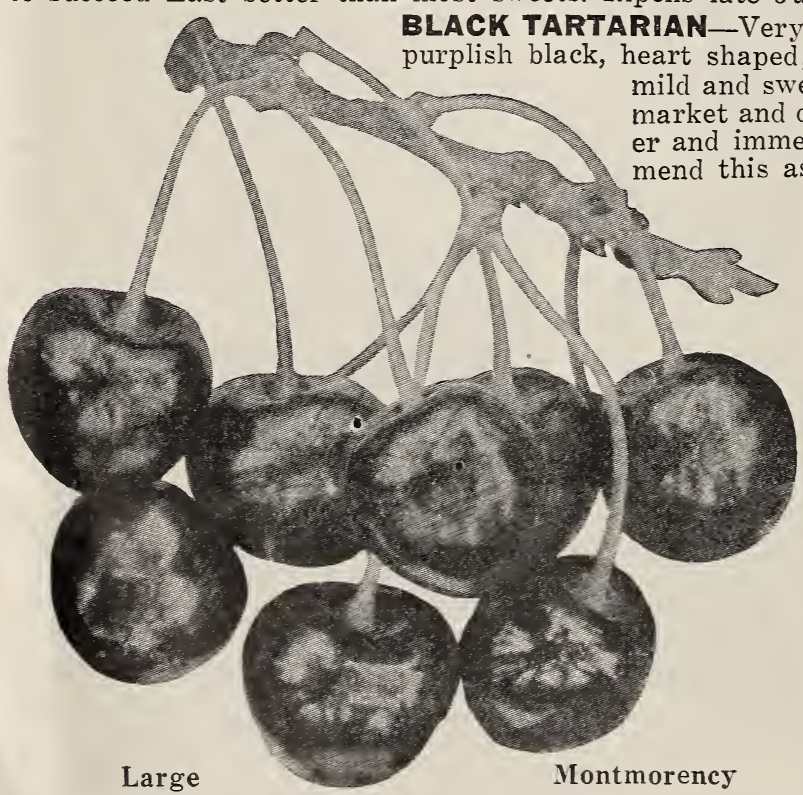

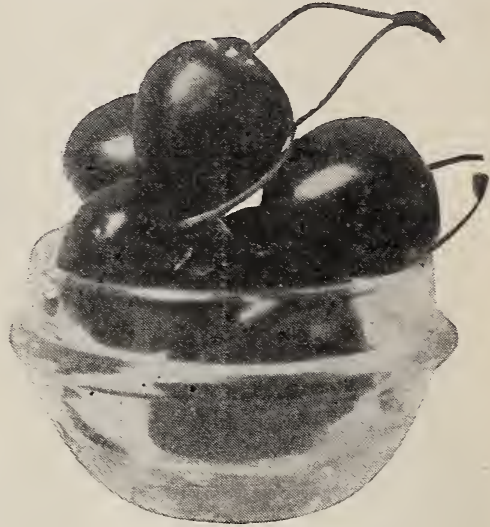

Black Tartarian BLACK TARTARIAN_-Very large
purplish black, heart shaped; ; flesh

quality considered of the best for 


\section{ORNAMENTAL SHRUBS}

BUDDIFIA-Butterfly Bush, or Summer Iilac. One of the most admired and sought after of shrubs. Of quick bushy growth. When the lovely spike-like shrub, which had probably died down nearly to the ground during winter, is now a perfect specimen of about five feet, radiating a delightful perfume and glowing with the tints and flower shape of the spring lilacs.

HYDRANGEA-P a nic u lat a Grandiflora. The most conspicuous shrub in any collection during August and September. It is easy to grow, never fails to bloom the first season planted, and produces in abundance immense clusters of greenish white flowers, which gradually delicate pink. Valuable for winter decorations if flowers are allowed to dry on bush.

FLOWERING AIMOND-(Pink) Early spring flowering shrub, usually in full bloom before leaves appear. Growth dwarf and bushy, compact, with slenuse in grouping or for the lawn. Flowers are very showy, and produced in great abundance.

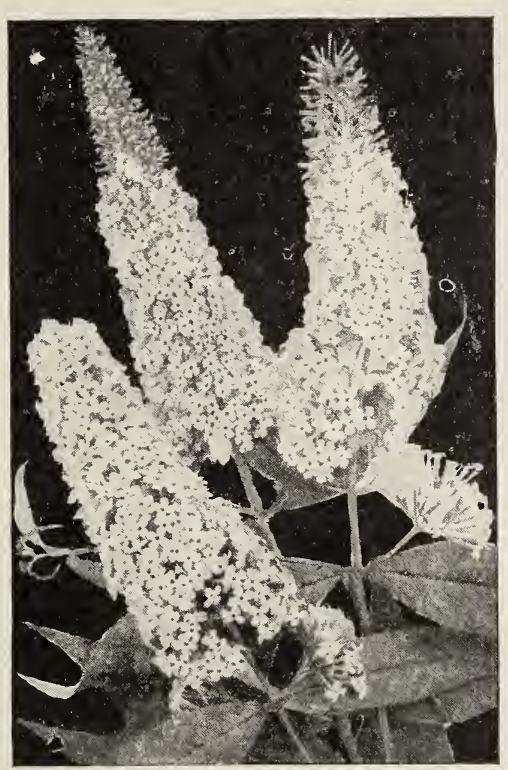

Buddeia, Butterfly Bush
DOGWOOD-Cornus Paniculata. One of the best native shrubs; when in bloom, and with its white fruits on red peduncles in the Fall.

SPIREA VAN HOUTTEI-Finest of all the Spireas, giving a most graceful appearance when pure white, and borne in dense pure white, and borne in dense of the branches. Excellent as a hedge plant, or for grouping with other shrubs.

MOCK ORANGE-Philadelphus Coronarius. A tall, hardy and vigorous bush. One of the best and most popular shrubs. Of good form, growing eight to ten feet tall. Blooms among the earliest, in very graceful sprays, the long branches being covered with a profusion of large. white flowers which are delightfully fragrant.

FORSYTHIA-(Intermedia). The earliest blooming. These splendid old shrubs light up the garden with glinting masses of yellow very early in the spring, and before the leaves appear. Their bright, golden flowers, of ten appearing before the snow is gone, vie with the crocus as in any locality.

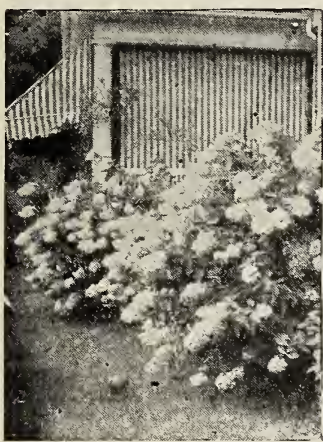

Hydrangea $\mathbf{P}$. G.

HONEYSUCKIF-Tartarian. The finest and best known of the bush honeysuckles. Has somewhat spreading branches, and bright green foliage. The
flowers are of bright pink color, followed by red berries, which ripen in midsummer, and cling to the bush for several weeks.

JAPAN QUINCE-Burning Bush. Very early in the spring this fine, attractive shrub is completely covshaped fruits that are quite fragrant she foliage is a dark. glossy green. A very desirable shrub.

IIIAC-Common Purple. One has to travel far to find anything that can outclass the old-fashioned Purple Lilac for sheer attractiveness, when in early spring its branches are a mass of gorgeous bloom and solid color, filling the air with its rich fraggrow fast, and will be blooming before you know it.

ALTHEA-Rose of Sharon. Beautiful shrub blooming late in August and September with a profusion Hibiscus and brightly colored flowers, much like the height, and make attractive specimens. Foliage particularly pleasing. Planted more compactly, and eccasionally pruned, are

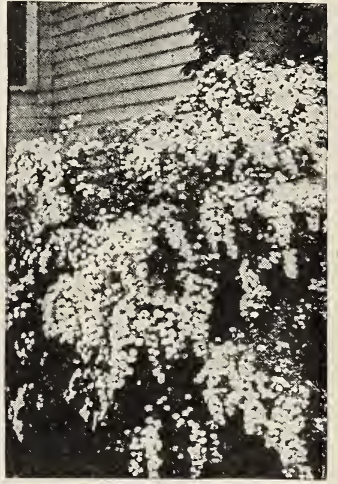

Spirea Van Fouttei

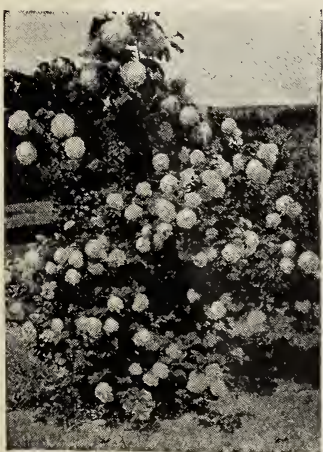

Snowball
SNOWBAII-Sterilis. The well known common snowball. An old favorite and without doubt one of the best of the flowering shrubs. All of the flowers are sterile and radiant, and appear in numerous, compact balls. As specimen plants the snowballs have no rivals, and for grouping and massing make possible many charming effects.

COMPLITE SELECTION OF POST PAID DOIIAR SHRUBBERY BARGAINS ON BACK COVER

We have given especial attention to our Ornamental Department, carrying a larger and more complete selection of varieties than the average nursery of our kind. $\$ 1.00$ postpaid anywhere in the U. S. Give your friends a chance to get in on these big offers with you. Any six Bargains for $\$ 5.50$. Every one listed on our Back Cover.

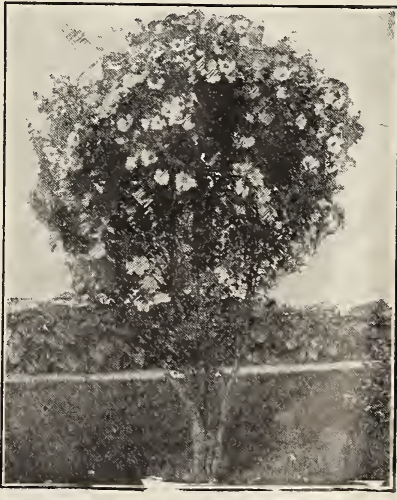

Althea, Rose of Sharon 


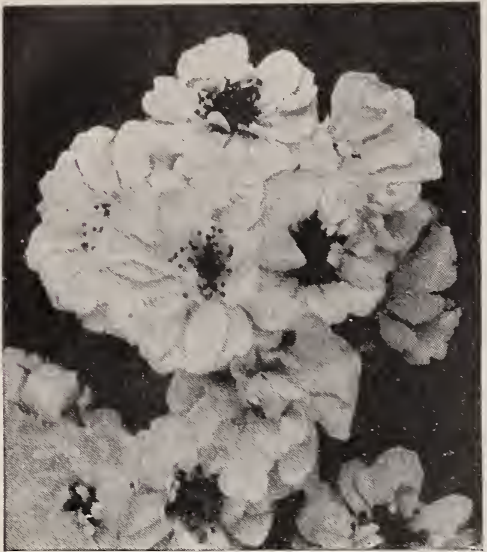

Bechtel's Flowering Crab

BECHTEL'S DOUBLE FLOWERING CRAB-A wonderful low, bushy tree, the most beautiful of disguise, and as sweet as the breath of Spring. At a distance the tree seems covered with dainty roses of delicate pink color. Blooms quite young. Admirers of Tree Roses highly pleased with the result.

SMOKE TRIE-Purple Fringe. Unicue, spreading tree-like shrub mid-summer by cloud-like masses of mist-like flowers having the appearance of smoke. Foliage changes autumn.

WEIGELA ROSEA-This is one of the most popular of all the Weigelas. A tall growing, vigorous sort with deep pink flowers, trumpet shaped, that are borne thickly along the stem in greatest of abundance during June. and more sparingly at intervals throughout the sum

TAMARIX - Africana. Tall shrubs, eight to ten feet tall, fine feathery foliage like the brioht pink flowers, in slender racemes in April and May. Splendid for planting damp or other places.

CAIIFORNIA PRIVET-On of the very finest all purpose hedges, and the most beautiful grown. A pretty shrub with smooth, shining leares of unusual beauty. There are many plants that may be used for the ornamental hedge with excellert results, but the great demand for California Privet proves it to be the most popular of all hedge plants. It grows better and with less care than any other hedge that can be planted, and thrives in almost any soil. Equally pretty for shrubs and in group planting. Shears splendidiy to any shape or winter injury in the coldest winter inj

AMOOR RIVER NORTH PRIVPT-Hardy for Northern climates. It is of similar form and habit to the well known California type. The foliage is not quite so in cold climates.

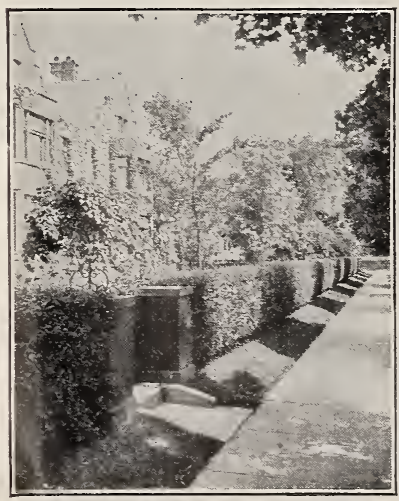

Amoor River North Privet

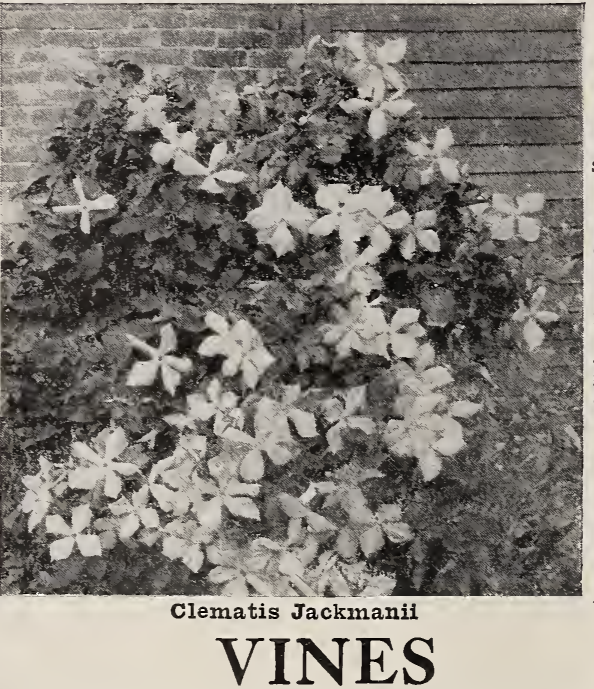

Vines may be used in many ways and places. Archways, arbors, pergolas, pathways and garden gates get their charm from well selected, deftly trained climbers. There is something about the sweeping and twisting of vines about the porch and the trellises about the house, that appeals to everyone.

CIFIMA TIS-Jackmanii. Immense flowers of an intense violet purple color that bloom continuously throughout the summer. We recommend this as one of the most striking and beautiful vines that can be planted.

CIFMATIS-Madam Andre. Plant is a good grower and a very free bloomer. Color a disall other varieties.

DUTCFMAN'S PIPE-A magnificent native vine of climbing habit and rapid growth, with magnificent light green foliage 10 to 12 inches in diameter, and curious pipe in shade.

KUDZU VINI-A grand hardy climber. Large foliage and dense shade. Will run 30 to 40 feet in one season. Flowers plentiful in August, rosy-purple, pea-shaped, in small racemes.

WISTARIA-Chinese Purple. One of the most elegant and rapid growing of all climbing plants. Attains an immense size, growing at the rate of 15 to 20 feet in a season. flowers in May and June, and in Autumn.

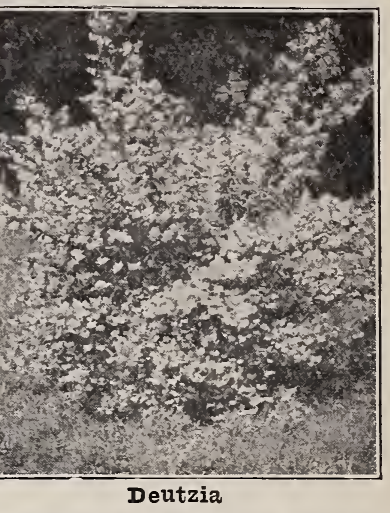

DEUTZIA-Pride of Rochester.-Produces large white flowers, tinged with rose. igorous grower, profuse to blossome of the hang in dainty bell or tassel-shaped fowers borne thickly in Ureal for Ur specimen groups or background for other adapts itself to any type of soil.

JAPANESE BARBERRYBerberis Thunbergii. Immune from rust. There is no shrub so generally planted or more practical for all purposes where foliage effects growing, uniformly bushy and rounded in form, numerous leaves covering thorny wigs. As a filler, edging for ther shrubbery, as foundation screen in front of porches. as a hardy, low hedge is unsurpassed. Foliage richest green throughout the richest green throughout the Spring and summer, while blaze of crimson, scarlet and gold. Following the creamy-white flower's are oval red along every branch in along every branch in Winter.

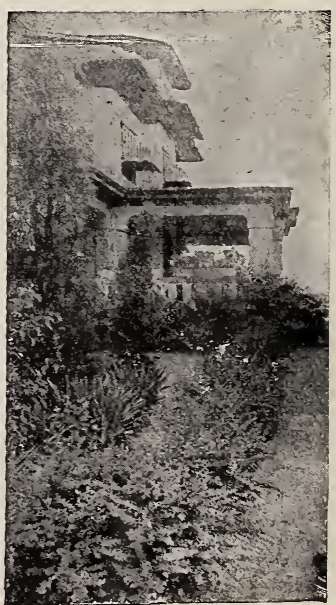

Japanese Barberry

NEW IMPERIAL EVERBEARER FREE TO EARLY CASH BUYERS. SEE PAGE 23. 


\section{Large Gladiolus Bulbs \\ POSTPAID FOR $\$ 1.00$ \\ BARGAIN NO. 2}

The Gladiolus is one of the most popular of all summer flowering: bulbs, being universally admired for its beautiful flowers, which give to the flower garden a touch of brilliant color at the time of year when it is most needed.

We have prepared for you one of the finest assortments of colors and varieties ever offered in any gladioli mixture, giving a wide range of color, and containing many of the popular varieties most frequently planted.

These are not bulblets, or small, undersized bulbs; every one being of full flowering size that will surely produce elegant spikes of bloom this summer. Place your order early for as many as you can use, as our supply is limited, and

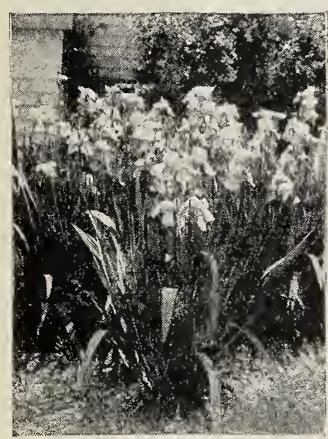
cannot he uplicated to sell at this low price of 40 This Price is Net, Subject to No Discount or Free This Price is Net, Subject to No Discount or
Plant Offer, and is for Cash with Order Only.

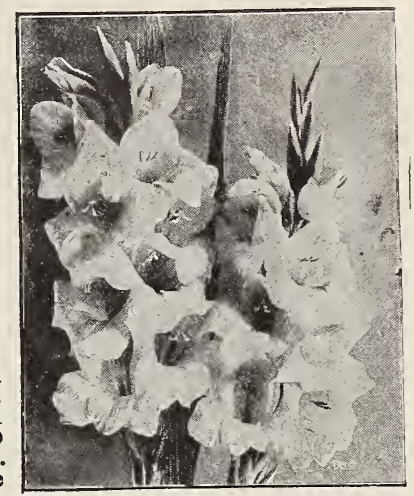

\section{Wonderful Iris Assortment 6e Each POSTPAID}

No Orders for Less than 10-As Many More As You Want BARGAIN NO. 3

The Iris is among the most interesting, enjoyable and highly developed of all families of flowers. All types have the common qualifications of delicacy in their blooms ; with broad sword-like, healthy evergreen foliage which lends itself to edging use after the flowers are gone. Wonderful landscape effects may be obtained by planting Iris in broad masses around the nargin of a yard, or along the banks of a stream. Our collection contains many different varieties, including many of the higher priced kinds that would cost from five to ten times our price if purchased singly by name. Our stock is all regular planting size.

Order all you need at this low price of $6 \mathrm{c}$ Each Postpaid Anywhere in the U. S. Sold Only in Lots of 10 or more. Price Net, Subject to No Discount or Free Plant Offer, and for Cash with Order Only.

\section{Large Flowering Dahlia Assortment}

BARGAIN NO. 4

Dallias are considered among the most beautiful and magnificent of the common garden plants, and should be found in every flower garden, no matter how small its size.

We are offering our customers an unusually complete as sortment, composed of many differnt kinds, including Decora tive, Cactus, Show and Pompon varieties. All Good Sized, Individual Tubers, Shipped Postpaid Anywhere in U. S., Six for $60 ;$ Twelve for $\$ 1.00 ; 25$ for $\$ 2.00 ; 8 \mathrm{c}$ Fach for Ádditional Quantities, as Many More as you want. Price Net, Subject to No Discount or Free Plant Offer, and for Cash with Order Only.

\section{Complete Everbearing Strawberry Garden BARGAIN NO. 5} Right in line with our practice of supplying customers with the best of nursery stock for the least money, we have posed of a sufficient number of two of the best everbearing varieties to keep the average table supplied with fresh strawberries every day from mid-summer until late Autumn, and all for $\$ 3.00$ postpaid-Think of it!

100 MASTODON (The World's Largest Everbearer).

50 CHAMPION (Heavy Producer)

Only $\$ 3.00$ Postpaid Anywhere in the U. S. Price Net, Sub iect to No Discount or Free Plant Offer, and for Cash wit? Order Only.

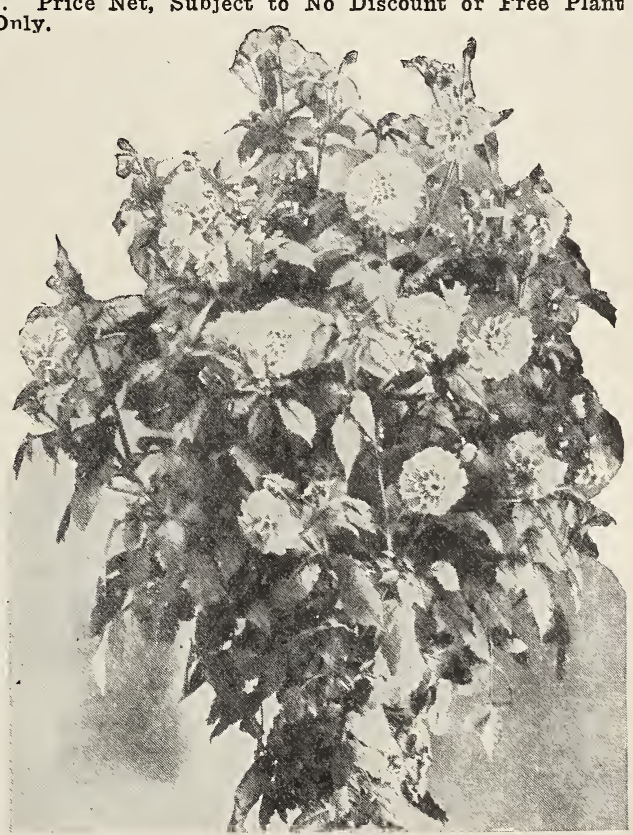

\section{Imperial Everbearing Strawberry Agreement}

I hereby agree that I will not sell, give away, nor otherwise dispose of any Imperial Everbearing Strawberry Plants furnished me by The Whitten-Ackerman Nurseries; and I further agree not to sell, give away, nor

IN WITNESS WHEREOF I have hereunto affixed my signature at

(Your Town)

Ir your order calls for Any Imperial, no matter whether purchased by you, or given as a premium with your nrder, it is Absolutely Necessary for you to Sign This agreement. Otherwise we cannot send the plants. 


\section{ORDER SHEET \\ Bridgman, Michigan}

The Whitten-Ackerman Nurseries

Order No.

Am't Rec'd.

Please Ieave Above Spaces Blank
If you are deducting $10 \%$ for cash with order place Check Here.

If you want order shipped C. O. D. purchase price for your approval place check here

\section{Am't Enclosed, \$}

Ship By

(Express or Mail)

Parcel Post Zone

(For Mail Shipments)

Be Sure To Fill In Above Spaces

Date

Name

R. F. D. or Street

Post Office

State

County

Town to Ship Express to

Ship on or about

Leave this space blank if you want us to use our judgment as to shipping date.

May we substitute if necessary?

(Please Answer Yes or No. Otherwise We Shall Assume We Are to Make Second Choice if Necessary)

\begin{tabular}{|c|c|c|c|}
\hline \multirow{2}{*}{ Quantity } & \multirow{2}{*}{ VARIETY } & \multicolumn{2}{|c|}{ Price } \\
\hline & & Dollars & Cents \\
\hline & Bargain Offers Nos. & & \\
\hline & & & \\
\hline & . & & \\
\hline & & & \\
\hline & & & \\
\hline & & & \\
\hline & & & \\
\hline & & & \\
\hline & & & \\
\hline & & & \\
\hline & & & \\
\hline s. & & & \\
\hline & & & \\
\hline & & & \\
\hline & & . & \\
\hline
\end{tabular}

FIEASE WRITE PLAINIY-DON'T FORGFT POSTAGE ON ILAII SHIPIIENTS. If your order includes Imperial Everbearer, be sure to sign Purchase Agreement on other side of sheet. And include six names if Imperial are given free with order. 


\section{CLIMBING ROSES}

AMERICAN BEAUTY-The famous American Beauty Rose in climbing form Has all the characteristics of its relative, including form and fragrance Healthy follage, and has strong climbing habit of growth.

CRIMSON RAMBIER-Will attain a height of 10 to 20 feet in a season. Produces a marvelous profusion of rich and are grown in pyramidal panicles, each carrying thirty to one hundred blooms.

DOROTHY PERIIN-A most beautiful shell pink. The flowers are borne in large clusters of small douile bloom, and are very sweet scented. This is undoubtedly the climbers, and is probably more extensively planted than any other.

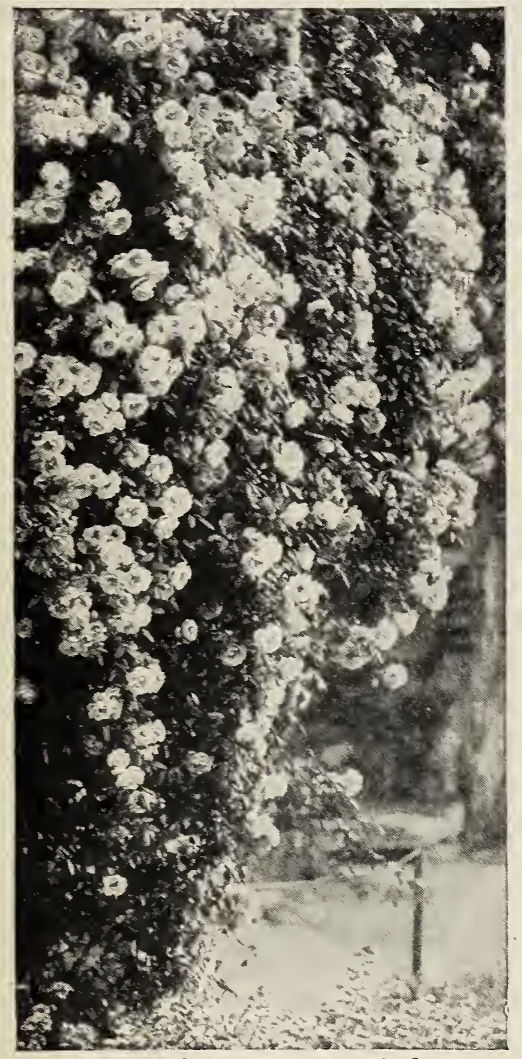

American Beauty Climber

\section{PEONIES}

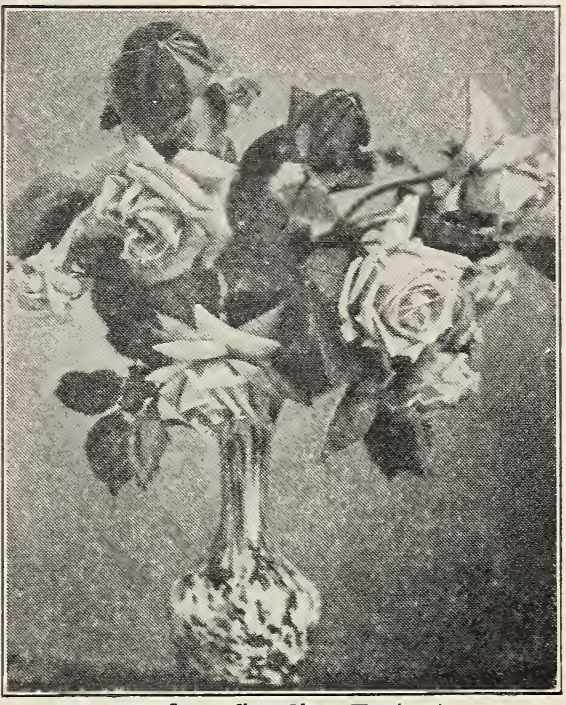

Madam Caroline Testout

\section{BUSH ROSES}

GENERAI JACQUEMINOT-(Hybrid Perpetual). Brilliant velvety crimson, large and extremely effective. A famous bud and forcing rose, quite as well adapted for garden culture. Very fragrant and one of the most popular sorts rown.

PAUI NEYRON-(Hybrid Perpetual). The largest rose in cultivation. Often produces blooms five inches in diameter. healthy, with clean, glossy foliage. June until late October. GRUSS AN TEPIITZ-(Hybrid Tea). Bright scarlet, shading to velvet-crimson; fragrant; free grower and most proding purposes.

KIIIARNEY PINK-(Hybrid Tea). Noted for its freedom of bloom, and the large size of its intensely fragrant flowers. Buds are large, long and pointed. Brilliant imperial pink

MAD. CAROIINE TESTOUT-(Hybrid Tea). Color bright, satiny rose, with darker center and edges of petals bordered with soft carmine-pink. Large, full flowers and handsome buds; fine for mass planting.

MRS. AARON WARD-(Hybrid Tea). The standard yellow rose. Flowers semi-double, cup shaped; fragrant. Blooms until frost.

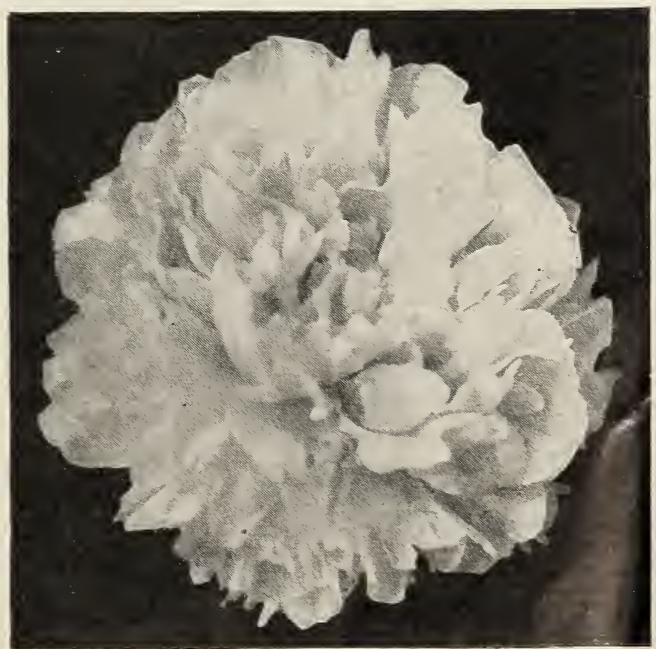

Festiva Maxima

Peonies are perfectly hardy, requiring no protection whatever, even in the most severe climate; and When once planted, increase in beauty each year. good strong three to five eye divisions, which we are offering at unusually low prices.

DORCHRSTRR-Beautiful shell pink. Large size and free bloomer. Fine for cutting and garden.

FrIIX CROUSSI-The leading red peony. Late: fine form, large ball-shaped bloom. Very brillian varieties.

FisTIVA MAXIMA-One of the earliest and best peonies. Flowers are very large, clear white, tipped with streaks of red Te cannot recommend this kind too highly. Has been one of the most popular and most heavily planted kinds for years past. Te have produced an excellent lot of extra fine, strong roots that we are offering at an exceptionally low price. chance to buy at our low figure. Prices on Page 23.

PLANT OUR NEW IMPERIAL EVERBEARER FOR BIG PROFITS 


\section{Whitten-Ackerman 1927 Wholesale Prices Direct To Planter (F. 0. B. Bridgman)}

TEN PER CENT DISCOUNT for All Cash With Orders Received Any Time During 1927; or We Will Ship C. O. D. for Your Approval Until April 20th, 1927, Without Any Deposit, at Prices Listed Below If You Prefer. STRAWBERRIES

\begin{abstract}
Per 12 Per 25
\end{abstract}
er 400

Premier

Bun Special

Sen. Dunlap

Dr. Burrill

Gibson

Eaton

Aroma

Pearl

Cooper

Champion Everbearing

Progressive Everbearing

Imperial Everbearing (Price on Inside Front Cover). RED RASPBERRIES

Cuthbert, 1-year, No- 1

King, 1-year, No. 1

. 140

Latham, 1-year, No. 1............................. 90

Latham, 2-year, No. 1 (Transplants) .......... 1.25

$\begin{array}{ll}\text { St. Regis, 1-year, No. } 1 \text {-................................... } & .45 \\ \text { St. Regis, 2-year, No. } 1 \text { (Transplants) }\end{array}$

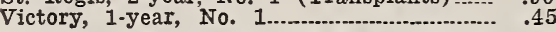
BLACK AND PURPIE RASPBERRIES

Cumberland, 1-year, No. 1 Tips._... \$0.45

Cumberland, 2-year, No. 1 (Transplants) .... 1.25

Plum Farmer, 1-year, No. 1 Tips. 1.25

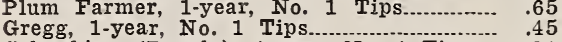

Columbian (Purple), 1-year, No. 1 Tips... $\quad .90$ BLACKBERRIES AND DEWBERRIES

Alfred, 1-year, No. 1 Root Cutting Plants..\$0.90

Eldorado, 1-year, No. 1 Suckers.................. .45

Eldorado, 1-year, No. 1 Root Cutting P1'ts .60

Mersereau, 1-year, No. 1 Root Cutting Pl'ts .60

Lucretia Dewberry, 1-year, No. 1 Tips....... ...45 ASPARAGUS

Mary Washington, 1-year, No, 1_\$0.25

Mary

Palmetto, 1-year, No. 1 .

Palmetto, 2-year, No. 1 RHUBARB

Myatt's Linnaeus, 1-year, No. 1 GRAPE VINES

Concord, 1-year, No. 1

Concord, 2-year, No.

Concord, 3-year, Extra Large

Moore's Early, 1-year, No. 1.

Champion, 2-year No 1 No. 1.

Niagara, 1-year, No. 1

Niagara, 2-year, No. 1

Delaware, 1-year, No. 1

Agawam, 1-year, No. 1

Wyoming, 1-year, No. 1

$\$ 0.25$

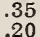

.20

Each ORNAMENTAL SHRUBS

Althea Rose of Sharon, 18.24 inch

Amoor River North Privet, 12-18 inch

Amoor River North Privet, 18-24 inch

Barberry Thunbergi, 1-year Hedging

Barberry Thunbergi, 18-24 inch

Bechtel's Double Flowering Crab, 2-3 ft.

California Privet, $2-3$ ft,

Deutzia, Pride of Rochester, 18-24 inch

Dogwood, 2-3 ft.

Dogwood, 2 ft.

Flowering Almond (Pink), 18.24 inch

Forsythia Intermedia, 18.24 inch.............

Hydrangea, P. G., 18-24 inch.-.

Japan Quince, $18-24$ inch.

Lilac, Purple, 2-3 ft.-

Mock Orange, 2-3 ft.

Smoke Tree, 18-24 inch

Snowball, 18-24 inch

Spirea V. H., $18-24$
Spirea V. H., $2-3$ ft

Spirea V. H., 2-3 ft.........

Tamarix Africana, $18-24$ inch

Weigela, Rosea, 18-24 inc

$$
\text { CIIMBING VINES }
$$

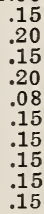

Clematis Jackmanii, 2-year, No.

Clematis Madam Andre, 2-year, No. 1

Dutchman's Pipe, 2-year, No. 1

Kudzu Vine, 2-year, No.

$$
\text { PEONIES }
$$

Festiva Maxima, 3 to 5 eyes

Felix Crousse, 3 to 5 eyes.. ROSES (See Prices at Top of Next Page.)

1.25
1.75

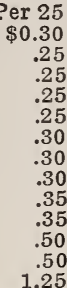

$\$ 0.75 \$ \$ 1.40$

$65 \quad \$ 1.40$

1.75

.75
1.25
.75

3.00
1.40

1.40
2.25

1.40

$\$ 0.75 \$ 1.40$

$\begin{array}{ll}1.75 & 3.00\end{array}$

1.00
.75

1.25

1.75

1.40
2.25

$\$ 1.50 \quad 2.75$

.75

2.75
1.40

1.70

1.70
1.40

Per 75
$\$ 0.70$

Per 100
S0.85

100
$\$ 0.85$
.75

Per 200
$\$ 1.30$
1.05
1.05

1.05
1.10

1.10

1.10
1.20
1.40

1.30

1.50

2.60

6.60

Per 300

$\$ 1.80 \quad \$ 2.20$

1.40
1.40

1.50

1.50

1.65
1.95

1.80

2.10
2.10

3.60

9.00

1.70

1.70
1.80

1.80

2.00
2.40
2.20

2.60
2.60
4.40

4.40

4.40
11.00

1000

$\$ 5.00$
3.75

3.75

4.00

4.00
4.50

5.50

5.00
6.00

6.00
6.00

10.00

25.00

$\$ 1.85 \quad \$ 2.2$

1.60

3.20

4.10

1.95
3.20

3.20
1.95

$\$ 2.25$
2.00

$\$ 3.90$

$\begin{array}{rrrrr}2.00 & 3.00 & 4.20 & 5.20 & 12.00 \\ 4.00 & 7.50 & 10.50 & 13.00 & 30.00\end{array}$

$\$ 5.40$

$\$ 6.60 \$ 15.00$

$\begin{array}{llll}9.50 & 13.50 & 17.00 & 40.00\end{array}$

$\begin{array}{rrrrr}2.50 & 4.00 & 5.70 & 7.20 & 17.00\end{array}$

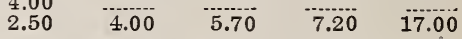

$\$ 1.85 \quad \$ 2.25$

$4.10 \quad 5.00$

$2.45 \quad 3.00$

$\begin{array}{ll}1.95 & 2.50 \\ 3.20 & 4.00\end{array}$

$\$ 4.00 \quad \$ 5.50$

$\$ 6.80 \$ 16.00$

$\begin{array}{llll}9.70 & 14.10 & 18.40 & 45.00\end{array}$

$\begin{array}{llll}5.30 & 7.40 & 8.90 & 20.00\end{array}$

$\begin{array}{rrrr}4.40 & 6.30 & 8.00 & 18.00 \\ 7.20 & 10.20 & 12.80 & 30.00\end{array}$

$\begin{array}{lllrrr}3.75 & 4.50 & 8.60 & 12.60 & 16.40 & 40.00\end{array}$

1.85

2.40

2.40
1.85

3.00

3.00
2.25

5.90

5.30

7.40

$\begin{array}{ll}6.60 & 15.00\end{array}$

$8.90-20.00$

$\begin{array}{ll}6.80 & 16.00\end{array}$

$\begin{array}{rrrrrrrr}\$ 0.40 & .70 & .95 & 1.25 & 2.00 & 2.75 & 3.40 & 8.00 \\ .60 & 1.00 & 1.40 & 1.75 & 3.00 & 4.20 & 5.20 & 12.00 \\ .30 & .50 & .70 & 1.00 & 1.60 & 2.25 & 2.80 & 6.50\end{array}$

$\begin{array}{llllllll}.45 & .50 & 1.70 & 1.00 & 1.60 & 2.25 & 2.80 & 6.50 \\ & .80 & 1.15 & 1.35 & 2.40 & 3.30 & 4.00 & 9.00\end{array}$

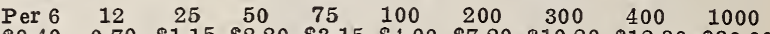

$\begin{array}{llllllllll}\$ 0.40 & 0.70 & \$ 1.15 & \$ 2.20 & \$ 3.15 & \$ 4.00 & \$ 7.20 & \$ 10.20 & \$ 12.80 & \$ 30.00\end{array}$

$\begin{array}{llllllllll}\$ 0.40 & .65 & 1.00 & 1.85 & 2.70 & 3.50 & 6.50 & 9.00 & 11.00 & 25.00\end{array}$

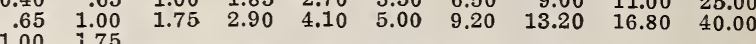

$\begin{array}{ll}1.00 & 1.75\end{array}$

$.75 \quad 1.25$

1.00

1.75
.70
1.00

1.25
1.25

1.25
1.25

1.25
1.25

Each

$\$ 0.20$

$2.00 \quad 3.50$

3.00
1.15

$\begin{array}{ll}1.75 & 2.90\end{array}$

$2.00 \quad 3.75$

$\begin{array}{ll}2.00 & 3.75 \\ 2.00 & 3.75\end{array}$

$\begin{array}{ll}2.00 & 3.75\end{array}$

$\begin{array}{llll}6.50 & 12.00 & 16.50\end{array}$

20.00

45.00

$\begin{array}{ll}7.50 & 9.00 \\ 2.80 & 3.50\end{array}$

\begin{tabular}{l}
$4.10 \quad 5.00$ \\
\hline .40
\end{tabular}

$\begin{array}{ll}\mathbf{5 . 4 0} & \mathbf{7 . 0 0} \\ \mathbf{5 . 4 0} & 7.00\end{array}$

$\begin{array}{ll}5.40 & 7.00 \\ 5.40 & 7.00\end{array}$

$\begin{array}{llll}8.50 & 12.00 & 15.00 & 35.00\end{array}$

612

12

7.00
25

25

$\$ 3.50$
1.75

$\begin{array}{lll}50 & 75 & 100\end{array}$

$\$ 6.00 \quad \$ 8.25 \quad \$ 10.00$

$\begin{array}{llr}3.00 & 4.00 & 4.50\end{array}$

\begin{tabular}{rrrrrrr}
5 & .85 & 1.55 & 3.00 & 5.50 & 7.85 & 10.00 \\
20 & 1.10 & -1.10 & 1.75 & 3.00 & 4.00 & 4.50 \\
\hline & -1.10 & 8.00 & 12.00 & 15.60
\end{tabular}

75 or 3 for $\$ 2.00$.

$\begin{array}{lr}1.35 & 2.65 \\ .60 & 1.15\end{array}$

$.85 \quad 1.65$

5 or 3 for $90 c$.

$\begin{array}{ll}2.70 & 4.80 \\ 85 & 1.65\end{array}$

.85
.85
$1.90 \quad 3.65$

$\begin{array}{ll}1.90 & 3.50 \\ 1.90 & 3.50\end{array}$

$1.50 \quad 2.75$

$.60 \quad 1.15$

2.70

2.70

.75
1.35

1.35
1.50

1.35

$\begin{array}{ll}\text { Each } & \text { Per } 3 \\ \$ 0.65 & \$ 1.75\end{array}$

$\$ 1.75$
1.75

1.00
.60

.60

Per 6 Per 12

$\$ 1.50 \quad \$ 2.75$

$\begin{array}{ll}4.40 & 4.20\end{array}$

$\begin{array}{llll}5.25 & 10.00 & 14.25 & 18.00\end{array}$

$\begin{array}{llll}2.25 & 4.25 & 6.00 & 7.50\end{array}$

$\begin{array}{llll}3.25 & 6.25 & 9.25 & 12.00\end{array}$

3.2

2.25

4.80
4.80
1.30

1.30
2.50
2.75

2.75
2.65

2.55

4.2

6.00

7.50

$55 \quad 5.0$

7.15

9.00

FRUIT TREES (See Prices at Top of Next Page.) 
ROSES

Dorothy Perkins, 2-year, No. 1

Crimson Rambler, 2-year, No. 1

American Beauty, 2-year, No. 1.

Paul's Scarlet, 2-year, No.

Paul Neyron, 2-year, No. 1

Gen. Jacqueminot, 2-year, No. 1

Mrs. Aaron Ward, 2-year. No. 1

Killarney Pink, 2-year, Nio.

Mad. Caroline Testout, 2-rear,

Gruss an Teplitz, 2-year, No. 1
Each Per 3 Per 10

$\begin{array}{lll}025 & \$ 0.65 & \$ 2.00\end{array}$

$\begin{array}{lll}30 & .80 & 2.50\end{array}$

$\begin{array}{lll}.35 & .95 & 3.00\end{array}$

$\begin{array}{lll}.40 & 1.00 \quad 3.25\end{array}$

$\begin{array}{lll}.40 & 1.00 & 3.25 \\ 40 & 1.00 & 3.25\end{array}$

$\begin{array}{lll}.40 & 1.00 & 3.25\end{array}$

1.35

$45-1.25 \quad 3.75$

3.75

\section{FRUIT TREES}

Each Per 10 Per 100 ft...\$0.30 $\$ 2.50 \quad \$ 20.00$ Peaches (all var.), 1-yr., medium... $.20 \quad 1.75 \quad 15.00$ Peaches (all varieties), 1 -yr., $4-6 \mathrm{ft}$. $.30 \quad 2.75 \quad 25.00$ Pears (all varieties), 2-yr., 4-6 ft.... $.60 \quad 5.50 \quad 50.00$ Plums (all varieties), 2-yr., 4-6 ft.... .45 $4.00 \quad 35.00$ Sour Cherries (all var.), 1-yr., 4-6 ft. $\quad .45 \quad 4.25 \quad 40.00$ Sweet Cherries (all var.), 1-yr., 4-6 .60 $5.50 \quad 50.00$ Apricots (Moorpark), 2- $\mathrm{\nabla r}, 4-6 \mathrm{ft} \quad-60 \quad 5.50 \quad 50.00$ Quinces (Orange), 2-yr., 4.6 ft........ $.60 \quad 5.50 \quad 50.00$

\section{BIG GIFT PLANTING OF IMPERIAL EVERBEARERS FREE TO EARLY CASH BUYERS}

(1) cash in full and who in addition sends the names and addresses of six fruit growers. or those really interested Everbearing plants.

Free with Cash Orders for less than $\$ 3.00$
2 Imperial Plants,
12 Imperial Plants, (Priced at $\$ 2.00)$, Free with Cash Orders between $\$ 3.00$ and $\$ 5.00$
25 Imperial Plants, (Priced at $\$ 3.50)$, Free with Cash Orders between $\$ 5.00$ and $\$ 10.00$
50 Imperial Plants, (Priced at $\$ 6.00)$, Free with Cash Orders between $\$ 1000$ and $\$ 15.00$
75 Imperial Plants, (Priced at $\$ 8.25)$, Free with Cash Orders between $\$ 15.00$ and $\$ 20.00$
100

100 Imperial Plants, (Priced at $\$ 10.00$ ), Free with Cash Orders amounting to $\$ 20.00$ or more.

The Above Offer Open Until March 25th, 1927, Only. Our supply of Imperial is too limited to permit our making this offer after March 25 th. Be sure to send the six nanes with your orcler, and also to sign the Imperial Agreement on back of order sheet. These plants positively will not be sent unless these conditions are complied with.

Cn all cash orders received after March $25 \mathrm{th}$, when accompanied by the six names above referred to, we will send additional nurserv stock of our own selection as to varie

\section{INSTRUCTIONS FOR ORDERING}

IOCAFION: Bridgman, Berrien County, Michigan-The Torld's Largest Fruit Plant Center.

Be Sure To Use Order Blank Provided on Page 20. It prevents Irrors, and Insures Prompt Attention. If You Do Not have an Order Blank, You INay Order By Letter.

ORDER EARIY: By ordering early you will find us with a full line of stock, and your order will be shipped when you want it, with no chance of delay. All early cash buyers receive a Liberal Gift Planting of Imperial Everbearers. Be one of them.

TERMS: 10 per cent discount on all orders accompanied by cash in full, except Special Bargain Offers. which are net. C. O. D. Express or Parcel Post shipment if you prefer. (See Page 4 for full details.)

CIAIMS: All claims covering condition on arrival, shortage or errors, must be made immediately upon arrival. If stock arrives in bad condition, be sure to furnish signed statement from express agent or postmaster, showing extent of loss or damage. All claims will be taken care of under the terms of our Guarantee printed on this page.

EXPRESS AND PARCEI POST SHIPMENTS: On express shipments, be sure there is an express office at destination you give Then ordering by Parcel Post be sure to include additional remittance sufficient to cover postage charges in accordance with schedule at bottom of this page.

SUBSTITUTION: In ordering be sure to state whether or not we shall substitute some other variety in case the kind ordered is exhausted. If not forbidden, we reserve the right to substitute some similar variety of equal or greater value, but will always label substitutes true to name.

FAII SHIPIMNTS: Our stock is fully matured by October 1st, and to southern customers or others wishing to plant in the Fall, we can make shipment auring October and November.

ACKNOWIFDGMENTS: Orders are acknowledged same day as received, and shipped in season, or as per instructions you give.

\section{OUR GUARANTEE}

TTe guarantee all of our nursery stock to be just as represented in our catalog; of good quality, free from disease, and absolutely true to name; also to reach the customer alive, and in perfect growing condition.

Furthermore. we will replace free of charge, or refund your money, on any stock that arrives in bad condition; providing claim is made immediately, and you give us a signed statement from the express agent or postmaster showing extent of loss or damage.

If any stock proves untrue to name it will be replaced free of charge, or purchase price will be refunded. but in no case will we be lesponsible for a sum greater than the original purchase price.

\section{PARCEL POST RATES}

\section{How IVuch To Include For Postage When You Send Cash With Order}

First locate the group of states in which vou live, and it will then be easy for you to determine from schedule below the proper amount to allow for postage on your order.

Group No. 1

Michigan

Northern Indiana
Group No. 2

Souther
Illinois

Iowa

Kentucky

Ohio

Tisconsin

Add to your order for each 100 plants

Strawberries and Asparagus

Red Raspberries

Black and Purple Raspberries,

Blackberries and Dewberrie

tree 3 to $4 \mathrm{ft}$.

5 trees 3 to $4 \mathrm{ft}$.

10 trees 3 to 4 ft

1 tree 4 to 5 or 5 to $6 \mathrm{ft}$

5 trees 4 to 5 or 5 to $6 \mathrm{ft}$.

Grape Vines, 5 or 5 to $6 \mathrm{ft}$..........................

mental shrubs, vines and Peonies.

\begin{tabular}{lc} 
Arkansas & Group No. 3 \\
Delaware & New York \\
Kansas & North Carolina \\
Maryland & Pennsylvania \\
Minnesota & Tennessee \\
Missouri & Virginia \\
\hline
\end{tabular}

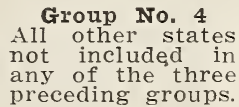

preceding oroups.

Missouri

Group
$\$ 0.10$
.15
.20
.08
.12
.20
.09
.14
.22

$\underset{\$ 0.15}{\operatorname{Group}}$ No. 2

Group No. 3 $\$ 0.20$

Group No, 4<smiles>[131In]</smiles>

.30

.40

.10

.18
.34

.12

.13
.29
.61
.37
.37
65

.85

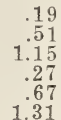




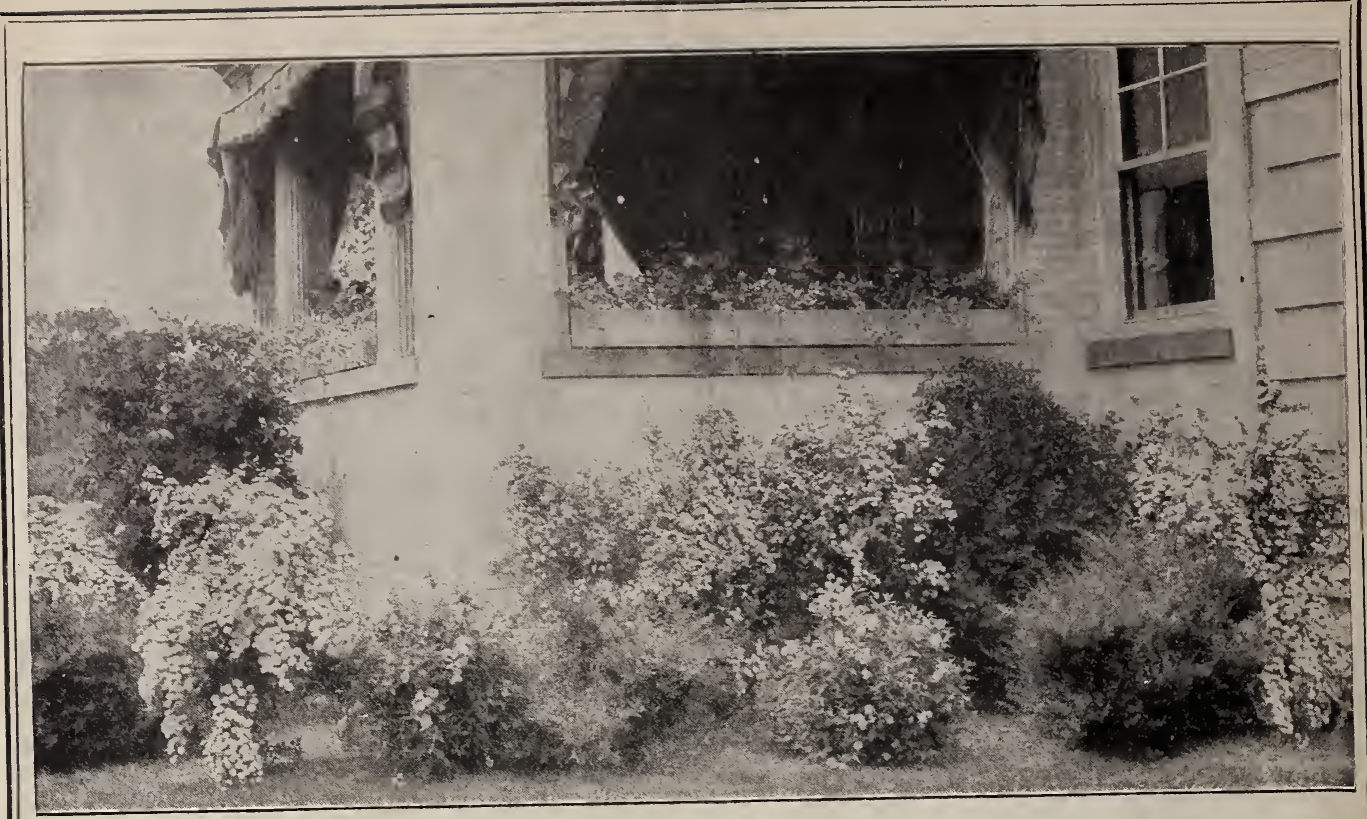

How would you like to have your home look like this? You can easily beautify your grounds, and create just as pleasing an effect by taking advantage of a few of the many bargains listed below. Wardener, and save our instructions loast 50 per cent.

\section{We want Thousands of New Customers this Year}

Once a Buyer-Always a Customer. Here's the Chance of a Life Time-Act Now? Every Offer Priced Without a Profit! This Is Our Way of Advertising.

$\$ 1.00$ BARGAINS-ANY SIX FOR \$5.50 POSTPAID ANYWHERE IN THE U. S. \$1.00 Bash With Order Only.

\section{OUR BEST GRADE ORNAMENTAL STOCK}

Bargain No, 6-5 Forest Trees, 3 to $4 \mathrm{ft}$. One Bargain No. 6-5 Forest Trees, 3 to 4 ft. One each Silver Maple, Amercan Maple. \$1.00.

lar, Tulip Tree and Scarlet River North Privet, 12 to 18 inch. $\$ 1.00$.

Bargain No. 8-15 Japanese Barberry, 1 yr. hedging size, and 6 Althea, Rose of Sharon, is to 24 ing size, and $\$ 1.00$

Bargain No. $9-2$ Hydrangè P. G. 18 to 24 inch, and 4 Mock Orange (Philadelphus) 2 to $3 \mathrm{ft}$. $\$ 1.00$.

Bargain No. 10-12 Mock Orange (Philadelphus) 2 to $3 \mathrm{ft}$. $\$ 1.00$. 10 Forsythia (Golden Bell) 18 to

24 inch. $\$ 1.00$ io Spirea V. H., 18 to 24 in. $\$ 1.00$. Bargain No. 13-12 Althea, Rose of Sharon, 18 to

24 inch. $\$ 1.00$. No. 1 Butterfly Bush, 1 Purple Bargain No. 14-1 No. Kudzu. Vine and 1 Chinese Purple Wistaria 18 to 24 inch. $\$ 1.00$.

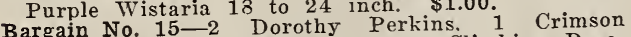

Bargain No. 15-2 Dorothy Perkins. $-^{2}$ American Beauty Climbing Rose, Rambler and 1 America

Bargain No. 16-1 Smoke Tree (Purple Fringe) 18 to 24 inch and 2 Tamarix Africana, 18 to 24 inch. $\$ 1.00$. Bargain No. 17-1 Bechtel's Double Flowering Crab inch si.00.

Bargain No. 18-12 Japanese Barberry, 1 yr. hedgBargain No. 18-12 Japanese Barberry, 1 yr. $\$ 1.00$. ing size, and 1 Snowbal Quince (Burning Bush) is to 24 inch. 2 Althea, Rose of Sharon 18 to 24 in., 2 Forsythia Intermedia, 18 to 24 in., and

All Bargains on this Page Are Taken from Our Regular Grade of Stock, Fully Guaranteed.

\section{CHOICE FRUITS FOR YOUR GARDEN}

Bargain No. 20-25 Mastodon, The Big Everbearer. $\$ 1.00$.

Bargain No. 21-50 Champion Everbearing and 50 Bargain No. $21-50$ surril strawberry. $\$ 1.00$.

Bargain No. 22-25 Dr. Burrill, 25 Eaton, 25 Gib. son and 25 Sample Strawberry plants. $\$ 1.00$.

son an No. 23-20 1 rr. Concord Grape Vines. $\$ 1.00$.

Bargain No. 24-10 each Victory, Cuthbert and King Red Raspberry Plants. $\$ 1.00$.

Bargain No. 25-10 each Victory, King and St. Regis Red Raspberry Plants. \$1.00.

Bargain No. 26-10 each Latham and Victory Red Raspberry plants. $\$ 1.00$.

Bargin No. 27-15 Alfred Blackberry plants. $\$ 1.00$. Bargain No. 28-12 each Mersereau and Eldorado Blar. Root. Cutting plants. $\$ 1.00$.

Bargain No. 29-15 St. Regis Everbearing Red Bargain No. $29-15$ St. Regis

Bargain No. 30-12 Extra Heavy Cumberland Black Raspberry Transplants. $\$ 1.00$

Bargain No. 31-25 Mersereau Blackberry Root CutBargain No. $31-25$ Lucretia Dewberry plants. $\$ 1.00$. Bargain No. 32-15 1-yr. No. 1 Niagara (White)

Grape Vines. $\$ 1.00$.
Bargain No. 33-25 each Mary Washington and Palmetto Asparagus, and 3 Myatt's Linnaeus Rhubarb, all 1 yr. No. 1 . $\$ 1.00$.

Bargain No. $34-4$ Apple trees, 3 to $4 \mathrm{ft}$., 1 each Delicious, Jonathan, Yellow Transparent and Wealthy. $\$ 1.00$.

Bargain No. $35-2$ Elberta peach and 2 Delicious apple, all 3 to $4 \mathrm{ft}$. $\$ 1.00$.

Bargain No. 36-4 peach trees 3 to $4 \mathrm{ft}$., 1 each Capt. Ede, Elberta, J. H. Hale and Rochester; or your choice of any four, all one variety only, \$1.00. your choice $37-1$ Montmorency and 1 Bing Cherry Bargain 4 ft. $\$ 1.00$.

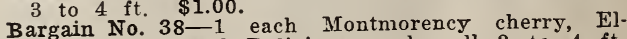
berta peach and Delicious apple, all 3 to $4 \mathrm{ft}$. $\$ 100$.

Bargain No. $39-2$ Burbank Plum 4 to $5 \mathrm{ft}$. and one Delicious apple, 3 to $4 \mathrm{ft}$. $\$ 1.00$. 